\title{
Ideology and Counter-Ideology From Lochner to Garcia
}

\begin{abstract}
J.M. Balkin*
In his dissent in National League of Cities $v$. Usery, ${ }^{1}$ Justice Brennan contended that the Court's opinion was reminiscent of the now rejected jurisprudence of the Lochner era: ${ }^{2}$

Today's [decision] can only be regarded as a transparent cover for invalidating a congressional judgment with which [the majority] disagree. The only analysis even remotely resembling that adopted today is found in a line of opinions dealing with the Commerce Clause and the Tenth Amendment that ultimately provoked a constitutional crisis for the Court in the 1930's. E.g., Carter v. Carter Coal Co., 298 U.S. 238 (1936); United States v. Butler, 297 U.S. 1 (1936); Hammer v. Dagenhart, 247 U.S. 251 (1918). . . . We tend to forget that the Court invalidated legislation during the Great Depression, not solely under the Due Process Clause, but also and primarily under the Commerce Clause and the Tenth Amendment. ${ }^{3}$
\end{abstract}

In his dissent in Garcia v. San Antonio Metropolitan Transit Authority, the case which overruled National League of Cities, Justice Rehnquist cryptically noted that the time would come when the Court would once again have to face the jurisprudential problems which gave rise to National League of Cities: "I do not think it incumbent on those of us in dissent to spell out further the fine points of a principle that will, I am confident, in time again command the support of a majority of this Court."

*Assistant Professor of Law, University of Missouri-Kansas City. A.B., 1978, J.D., 1981, Harvard University. I would like to thank my research assistant, Linda Talley, for her help in the preparation of this Article, and my colleagues John Scurlock and Jim Kushner for their comments on a previous draft.

1. 426 U.S. 833 (1976). In National League of Cities, the Court held that the tenth amendment prevented Congress from extending the minimum wage and overtime provisions of the Fair Labor Standards Act to state and local governmental employees.

2. Lochner v. New York, 198 U.S. 45 (1905) (striking down state maximum hour law for bakers). The Lochner era was characterized by reactionary decisions of the Supreme Court in matters relating to economic regulation. Although the formation of its characteristic ideology can be seen in the 1880 s, the Lochner era is generally considered to have begun with the decision in Allgeyer v. Lousiana, 165 U.S. 578 (1897); it continued until the Supreme Court's decisions in West Coast Hotel Co. v. Parrish, 300 U.S. 379 (1937), and NLRB v. Jones \& Laughlin Steel Corp., 301 U.S. 1 (1937). Throughout this Article, the words "Lochner Court" refer to the Court during this period, and not simply to the Justices who decided Lochner v. New York.

3. 426 U.S. at 867-68 (Brennan, J., dissenting).

4. U.S. 105 S.Ct. 1005 (1985). Garcia held that the minimum wage and overtime provisions of the Fair Labor Standards Act were constitutional as applied to employees of the San Antonio Metropolitan Transportation Authority.

5. Id. at 1033. There is some dispute as to what exactly Justice Rehnquist meant by his short dissent in Garcia. Perhaps Justice Rehnquist was merely adverting to the fact that the next ap- 
Although Justice Brennan and Justice Rehnquist are poles apart on many issues, I suggest that both are right in their assessments of National League of Cities and Garcia. There is a deep connection between the jurisprudence of the Lochner era and Justice Rehnquist's majority opinion in National League of Cities, just as there is a deep connection between Garcia and the cases that brought the Lochner era to a close. To that extent Justice Brennan is certainly correct.

On the other hand, the Court has found that in the post-1937 era it is not easy to escape the implications of Lochner; every time the Court invokes a high level of scrutiny to protect a preferred liberty, it is subject (rightly or wrongly) to the charge of anti-majoritarian tyranny. ${ }^{6}$ Yet at the same time the Court has often seen the need for a high level of judicial scrutiny to protect preferred liberties (or the fairness of the democratic process). Similarly, I think, the Court's recent rejection of National League of Cities and its abdication of any judicial role in protecting state interests mask difficult problems that will simply not go away. Those problems concern the responsibilities and limitations of federal courts in exercising judicial review, and the need to enforce and protect the proper relationships of power between the states and the federal government. The Court will have to face those problems again, even after Garcia, and to that extent, Justice Rehnquist is also correct.

The goal of this Article is to demonstrate that the ideological structure of cases dealing with judicial review of economic regulation (including both commerce clause and due process cases) is recapitulated at a different level in the ideology" which underlies National League of Cities. In addition, this Article

pointment to the Supreme Court would likely be a conservative who would help to reverse the 5-4 result in Garcia. If so, that is hardly a proper justification of a position in a Supreme Court opinion. I choose to read Justice Rehnquist as pointing out that it was the duty of the federal judiciary to protect state interests, and that this was an idea whose time would come again. See also id. at 1038 (O'Connor, J., dissenting) ("Regardless of the difficulty, it is and will remain the duty of this Court to reconcile [state and federal] concerns in the final instance. . . . I share Justice Rehnquist's belief that this Court will in time again assume its constitutional responsibility."). Of course, it is possible that Justice Rehnquist was making both points.

6. E.g., Griswold v. Connecticut, 381 U.S. 479, 507-27 (1965) (Black, J., dissenting).

7. By "ideology" I mean simply a world view which involves beliefs about both facts and values. An ideology often combines assertions about what is and what ought to be in an inextricable fashion. For example, people with a given ideological bent may believe both that a lot of people on welfare do not want to work and that people should sink or swim on their own without help from others. The two assertions (and their factual and normative predicates) are interdependent.

It is characteristic of an ideology that it is both partially a true reflection of the world and a distortion or falsification of it. For example, in the Lochner era the Court saw the freedom of persons to engage in economic transactions as an essential aspect of liberty. This ideological assertion did reflect a truth about human nature; human dignity does require that, to some extent, people have freedom to choose their own goals, freedom to choose how they will use their own property, and freedom to choose how they will earn a living. At the same time, the Court's exaltation of liberty of contract concealed the economic coercion that may result in a regime of free contract where parties have vastly different amounts of economic resources and bargaining power.

As the term is commonly used, "ideology" bears pejorative connotations, and that is no doubt due to the aspect of "false consciousness" which the term implies. However, because ideologies are 
seeks to show that the decisions of the Roosevelt Court in the late 1930s and early 1940s which dismantled Lochner represent a counter-ideology. These decisions established a new orthodoxy about the proper scope of judicial review in economic regulation cases which is mirrored in the modern Court's abandonment of National League of Cities in the cases leading up to and including Garcia.

To put it another way, there is a common ideological bias which National League of Cities shares with the decisions of the Lochner era, decisions like Lochner v. New York, Adkins v. Children's Hospital, ${ }^{8}$ Hammer v. Dagenhart, ${ }^{8}$ and Carter $v$. Carter Coal Co. ${ }^{10}$ Those decisions, and the ideology which spawned them, were replaced by new decisions and a counter-ideology for judicial review in economic regulation cases. This new ideology is typified by cases like West Coast Hotel Co. v. Parrish," United States v. Carolene Products Co. ${ }^{12}$ NLRB v. Jones \& Laughlin Steel Corp. ${ }^{13}$ and United States v. Darby. ${ }^{14}$ National League of Cities, in turn, represented a counter-insurgency of the former ideas, an attempt to reestablish the old ideology in a limited sphere of doctrine. However, the ideology of that case was in direct conflict with the ideology of the post-1937 era. Ultimately, the tension between this new ideology and the old ideology could not be withstood, and in Garcia, the Court reaffirmed post-1937 ideology even in the limited sphere marked out by $\mathrm{Na}$ tional League of Cities.

The structure of this Article is as follows: First, I describe the major features of Lochner era jurisprudence in economic due process and commerce clause cases. Second, I explain how each of these features was replaced with its opposite in the post-1937 era, which represents the growing dominance of a counter-ideology. Third, I show how each of the features of Lochner era jurisprudence reappear in a new form as the ideological underpinnings of the majority opinion in National League of Cities, and the dissenting opinions in the cases which followed it. And finally, I show how the contradictions between

partly true as well as partly false visions of the world, and because they have an important explanatory and apologetic function, they cannot be so easily dismissed. It is to some extent impossible to exist as a social and political being without owing allegiance to some forms of ideological thinking. The history of political societies is the history of clashes of ideologies with counter-ideologies, which appear and reappear with the flow of social, political, and economic events.

8. 261 U.S. 525 (1923) (striking down minimum wage laws for women and children).

9. 247 U.S. 251 (1918) (striking down federal ban on shipment of interstate goods made by factories which used child labor).

10. 298 U.S. 238 (1936) (striking down the Bituminous Coal Conservation Act of 1935, which set maximum hours and minimum wages for coal miners).

11. 300 U.S. 379 (1937) (upholding a state minimum wage law for women).

12. 304 U.S. 144 (1938) (upholding federal prohibition of the interstate shipment of "filled milk").

13. 301 U.S. 1 (1937) (upholding the National Labor Relations Act of 1935).

14. 312 U.S. 100 (1941) (upholding the Fair Labor Standards Act of 1938, which imposed federal minimum wage and maximum hour regulations for employees engaged in the production of goods for interstate commerce). 
National League of Cities and the dominant post-1937 ideology led to the overruling of the case in Garcia.

\section{THE IDEOLOGY OF THE LOCHNER ERA}

The Supreme Court's decisions in the Lochner era shared several important features: (1) a preference for economic individualism and freedom of contract; (2) a preference for state regulatory power over federal; (3) a conceptualist mode of analysis; (4) a reliance on the public/private distinction; and (5) a high level of judicial scrutiny and an assertion of judicial authority and competence in cases concerning economic regulation. Each of these aspects of Lochner era ideology will be discussed in turn.

\section{A. Individualism and Freedom of Contract}

The most characteristic feature of Lochner era jurisprudence was a preference for individualism in legal rules which concerned economic regulation. As I use the term, individualism is a mode of thought which denies the responsibility of persons for the consequences their behavior has on others, and which affirms the right of individuals to act free from governmental coercion. ${ }^{15}$ Hence, in matters of economic regulation, individualism is associated with a policy of laissez-faire and freedom of contract. The late nineteenth century Supreme Court exercised a preference for a theory of economic individualism when it discovered a constitutionally protected freedom of contract in the due process clause of the fifth and fourteenth amendments. It was this clause which the Lochner Court used to strike down state and federal legislation which regulated terms and conditions of employment. According to the reigning jurisprudence of the time, such regulations abridged the right of both employer and employee to form contracts of employment (or to refuse to form such contracts). ${ }^{16}$

The Court's preference for freedom of contract is obvious in cases like Lochner v. New York, Coppage v. Kansas, ${ }^{17}$ and Adkins v. Children's Hospital. The Court's general hostility to restrictions on freedom of contract is not explicitly stated in many of the same Court's commerce clause opinions, but it helps explain why members of the Court who supported a broad view of freedom of contract would support a narrow view of federal power under the commerce clause. ${ }^{18}$

15. See generally Kennedy, Form and Substance in Private Law Adjudication, 89 HaRv. L. REv. 1685 (1976); Balkin, The Crystalline Structure of Legal Thought (Jan. 10, 1986)(unpublished manuscript).

16. E.g., Adkins v. Children's Hosp., 261 U.S. 525 (1923); Coppage v. Kansas, 236 U.S. 1 (1915); Lochner v. New York, 198 U.S. 45 (1905).

17. 236 U.S. 1 (1915).

18. In fact, in Adair v. United States, 208 U.S. 161 (1908) and Carter v. Carter Coal Co., 298 U.S. 238 (1936), the Court held regulatory legislation unconstitutional on both due process and tenth amendment grounds. 208 U.S. at 180; 298 U.S. at $293,311$. 
Consistent with a philosophy of individualism, a regime of free contract decentralizes economic power by shifting it from the governmental regulator to individual economic actors. Instead of the government imposing terms and conditions of employment on the parties, the parties themselves would use their economic power to achieve whatever terms and conditions they could bargain for in individual market transactions. In addition, the theory of the "invisible hand" supported decentralization of economic power by claiming that the best consequences to society would occur by permitting each individual to exercise his economic power in the way he thought fit. Thus, in the ideology of the Lochner Court, expansion of individual freedom was associated with decentralization of power from a central government into smaller individual economic decision making units.

Moreover, under the individualist vision, governmental regulation of the terms and conditions of contracts of employment did more than simply abridge the rights of freely contracting parties. It also redistributed power and income from one group of persons to another. This redistributive effect seems inevitable, since it was obviously the purpose of the legislature to impose terms in some contracts that the parties themselves would not have agreed upon given their respective economic power and bargaining positions. For example, a minimum wage law eliminates the opportunity that an employer in a superior bargaining position has to offer a job below a certain wage. Because this goal is denied him, he must exercise his superior economic position in other ways. In sum, the Lochner Court saw regulation of the marketplace not only as an inappropriate centralization of economic power in the government, but as an unjustified attempt by popularly controlled legislatures to redistribute economic power. ${ }^{19}$

\section{B. State Regulatory Power Preferred to Federal}

There is a subtle connection between the Lochner Court's economic libertarianism and its hostility to the growth of the federal power to regulate interstate commerce. In the first place, the vision of states' rights the Court found in the tenth amendment represented a decentralization of regulatory power from the federal government to the states, which was analogous to the decentralization of regulatory power from government to the individual created by a regime of free contract. In other words, if one thinks of the states as individuals bound together in a league, both the states' rights and freedom of contract positions seem very individualistic.

Second, if the Court was hostile to widespread economic regulation of the economy, which would undoubtedly infringe upon freedom of contract, it made sense to scrutinize federal regulation of interstate commerce, which almost always had this effect. Thus whenever the Court struck down a federal regulatory statute as beyond the powers of Congress, it was striking a blow not only

19. See, e.g., Coppage v. Kansas, 236 U.S. 1, 17-18 (1915). 
for states' rights but also for freedom of contract. ${ }^{20}$

\section{Conceptualism}

Another important feature of Lochner era jurisprudence was the Court's use of a conceptualist style of reasoning; that is, basing legal decisions not on empirical data, but instead upon abstract concepts, often derived from the common law. A good example of conceptualism in the due process cases involved in Lochner itself, in which the Court struck down a maximum hour law for bakers. The Court held the law unconstitutional because it violated the equal right of the baker and the employer to enter into a freely negotiated arm's length agreement. Simultaneously, the Court distinguished its holding of the constitutionality of a similar law for the benefit of miners ${ }^{21}$ on the ground that mining was an inherently dangerous activity, an idea which appears to be derived from common law tort concepts of ultra-hazardous activities and nuisance. ${ }^{22}$

Conceptualist forms of reasoning covered the political nature of judicial choices under a veneer of scientific investigation, absolute moral principle or logical certitude. For example, the abstract notion of freedom of contract was associated with an idealized notion of the individual's assertion of will. The Court's vindication of this abstraction disguised various forms of economic coercion. A good example of this is Coppage v. Kansas, where the Court struck down a prohibition on "yellow dog" contracts (employment conditioned upon a promise that a prospective employee would not join a labor union), noting that the freedom to bargain was "as essential to the laborer as to the capitalist, to the poor as to the rich."2s The inequalities of bargaining power between workers and employers were irrelevant to the vindication of the abstract right: they were "but the normal and inevitable result" of the right of free contract. ${ }^{24}$ In this way, the abstract concepts that the Court adopted in its jurisprudence

20. In the modern (post-1937) era increased federal power is still more likely than not to be identified with limitations on freedom of contract and a liberal social agenda. Federal Civil Rights legislation is a prime example of this. In Heart of Atlanta Motel v. United States, 379 U.S. 241 (1964), and Katzenbach v. McClung, 379 U.S. 294 (1964), the Court rejected attacks on the Civil Rights Act of 1964, which regulated private discriminatory decisions made by owners of places of public accommodation. These regulations in effect altered the freedom of contract of the discriminators in favor of the rights of minorities. See infra text accompanying notes 53-57.

21. Holden v. Hardy, 169 U.S. 366 (1898).

22. Lochner, 198 U.S. at 54-55. A similar distinction was used to justify Congressional laws which prohibited interstate shipments of lottery tickets, Champion v. Ames (Lottery Case), 188 U.S. 321 (1903); alcohol, Clark Distilling Co. v. Western Md. Ry., 242 U.S. 311 (1917); and prostitutes, Hoke v. United States, 227 U.S. 308 (1913), while at the same time striking down a congressional ban on transportation of goods manufactured by the use of child labor, Hammer $v$. Dagenhart, 247 U.S. 251 (1918). The former were within Congress' power because the things prohibited were harmful in themselves, while the products of factories using child labor were not. Hammer, 247 U.S. at 271.

23. 236 U.S. 1, 14 (1915).

24. Id. at 19-21. 
served to buttress and justify both its individualist penchant and a particular distribution of economic power.

A conceptualist approach was manifested in several different ways in the commerce clause cases of this era. The earliest example was the Court's identification of commerce with movement, whether water or rail traffic. As a consequence, mere manufacture, which was thought to be rooted to the place where manufacture took place (a factory), was considered essentially local in nature and hence not interstate commerce. ${ }^{25}$ The effect of this conceptual scheme was that contracts of employment in manufacturing industries could not qualify as interstate commerce.

A similar conceptual gambit had led to the earlier holding in Paul $v$. Virginia $^{28}$ that a contract of insurance did not constitute interstate commerce, because a contract is signed and takes its legal effect according to the place where it is entered into. ${ }^{27}$ This conclusion borrows heavily from nineteenth century ideas about choice of laws which were being formulated at this time. A contract was not viewed as a moving thing or a thing that could be placed in the stream of commerce, hence it was not subject to regulations of interstate commerce.

The connection between this decision and economic individualism is obvious. If contracts of insurance are not instrumentalities of interstate commerce, then that in and of itself guarantees that a great many possible restraints on freedom of contract by the federal government are preempted.

By far the most important conceptualist invention of the Lochner Court was the distinction between activities which directly affected interstate commerce, and those which indirectly affected interstate commerce. Congress could regulate activities which affected interstate commerce, ${ }^{28}$ but the effect on interstate commerce had to be direct and logical. ${ }^{29}$

25. E.g., United States v. E.C. Knight Co., 156 U.S. 1 (1895); Kidd v. Pearson, 128 U.S. 1 (1888). Conversely, the Court was willing to extend the commerce power in cases where the government could show an insertion of a commodity into the "current of commerce" or "stream of commerce," once again invoking a concept of movement. See Stafford v. Wallace, 258 U.S. 495 (1922); Swift \& Co. v. United States, 196 U.S. 375 (1905).

Where regulation of rail rates was involved, as in Houston, E. \& W. Tex. Ry. v. United States (The Shreveport Rate Case), 234 U.S. 342 (1914), or Railroad Comm'n of Wis. v. Chicago, B. \& Q. R.R., 257 U.S. 563 (1922), the Court was quite willing to acknowledge that intrastate transportation could have significant effects on interstate transportation; therefore Congress could justifiably regulate the former as well as the latter under the commerce clause. That favoritism for local commerce would produce an unfair impact on interstate commerce was obvious to the Court in rate cases, but not obvious to the Court in a case involving manufacturing, like Hammer $v$. Dagenhart.

26. 75 U.S. (8 Wall.) 168 (1869). Like several of the commerce clause cases, this case actually pre-dates the "official" beginning of the Lochner era in 1897. Looking only at the due process cases does not give an adequate picture of the intellectual building blocks which gradually developed into the Lochner ideology.

27. Id. at 183-84.

28. E.g., The Shreveport Rate Case, 234 U.S. 342 (1914).

29. E.g., United States v. E.C. Knight Co., 156 U.S. 1 (1895). 
An excellent example of how this conceptualist approach served the ideology of economic individualism is Carter v. Carter Coal Co., ${ }^{30}$ in which the Court struck down the Bituminous Coal Conservation Act. The Act created a federal excise tax on coal and then granted a partial exemption from the tax as a financial incentive to coal producers to abide by certain wage, labor, and price-fixing regulations. The Court argued that the minimum wage and labor regulations of the Act, affecting as they did the relations between coal miners and their employers, primarily affected production and not interstate commerce. $^{31}$

Justice Sutherland's majority opinion had to deal with the obvious argument that regardless of the local nature of coal mining operations, it was undeniable that if there were labor unrest, interstate commerce would be severely hampered by a resulting lack of a steady supply of coal. After all, coal was necessary as fuel for railroads, for the steel industry, and so forth. However, according to Sutherland, it was not the amount of the effect that coal mining had on interstate commerce that was important, but rather the nature of the effect, that is to say, whether the effect was direct or indirect. ${ }^{32}$

The use of concepts like direct and indirect causation were intimately related to the individualist ideological basis of Lochner jurisprudence. When Sutherland argued that the effect on interstate commerce was only indirect, ${ }^{33}$ he was really saying that the problem of labor relations was a local problem between the local employer and his employees, even if it had effects which went beyond the locality of its origin. This claim is connected to the Court's preference for freedom of contract. The relations between employer and employee are their own business and nobody else's, and for the government to alter these relations based upon the effects that a private contract had on third parties would be to deny the local and autonomous character of contracts. Contracts, and especially employment contracts, were private, local relations between parties which could not be interfered with regardless of the effects that they had on others. This is what Sutherland meant when he stated that working conditions were local conditions. ${ }^{34}$ This attitude is consistent with individualist philosophy, which denies the responsibility of actors for the effects that their actions have on others in society.

\section{The Public/Private Distinction}

A special case of the Lochner era's conceptualism was a narrow conception of permissible public purposes. While the safeguarding of health, safety, welfare, or public morals was considered a permissible public purpose, the mere shifting of economic bargaining power so as to improve distributional conse-

30. 298 U.S. 238 (1936).

31. Id. at 304 .

32. Id. at 307-09.

33. Id. at 309 .

34. Id. at 308 . 
quences in society was not considered a valid public purpose. The Court saw this type of legislation as mere redistribution, and failed to recognize that distributional effects which aid some groups over others can simultaneously advance legitimate public policies as well. In essence, the Court's ideology was based upon a rigid distinction between public purposes and private purposes.

This public/private distinction explains the Court's hostility to minimum wage and maximum hour laws in Adkins $v$. Children's Hospital and in Lochner itself, as well as its hostility to pro-union legislation in Adair $v$. United States" and Coppage v. Kansas (both of which involved "yellow dog" contracts); all of these laws were seen as essentially redistributive forms of legislation which served no legitimate public purpose. ${ }^{36}$

Along with the pinched conception of public purposes that the Court was willing to grant the states, the Court had an even narrower conception of permissible public purposes that the federal government could seek to achieve through its regulation of interstate commerce. After all, if the Lochner Court did not believe that redistributional goals were permissible goals of the states' police power, it is not surprising that it did not think that the federal government had any general police powers.

I have already noted the analogy between a states' rights position and economic individualism; both positions argue for a form of decentralization of economic power. Similarly, there is a connection between the Court's hostility to regulations of freedom of contract which have redistributive effects between individuals and the Court's hostility to regulations of interstate commerce which change the relative economic positions of different states.

This connection is most pointed in Hammer $v$. Dagenhart, ${ }^{37}$ in which the Court struck down a ban on the shipment of goods produced within thirty days by factories which employed children under fourteen or employed children between fourteen and sixteen for more than eight hours a day.

The obvious purpose of the child labor statute was to coerce persons in states which did not have child labor laws either to stop employing children or shorten the children's hours. Congress' goal, therefore, was to achieve the same effect as would occur if all the states had individually passed child labor laws. However, the lack of child labor laws in many states was not merely due to

35. 208 U.S. 161 (1908).

36. On the other hand, the Court was willing to permit economic regulation in businesses "affected with a public interest." New State Ice Co. v. Liebmann, 285 U.S. 262 (1932); Williams v. Standard Oil Co., 278 U.S. 235 (1929); Tyson \& Brother v. Banton, 273 U.S. 418 (1927); Chas. Wolff Packing Co. v. Court of Indus. Relations, 262 U.S. 522 (1923); Munn v. Illinois, 94 U.S. 113 (1876). The distinction between business affected and not affected with a private interest simply recapitulated the public/private distinction at another level.

As the Lochner ideology began to fall apart in the 1930s, the Court began to realize that almost any industry could be affected with a public interest, in that control of any industry might serve the public good. Nebbia v. New York, 291 U.S. 502 (1934). The destruction of the distinction between businesses affected and not affected with a public interest was simply another feature of the characteristic decline of the public/private distinction in the post-1937 period.

37. 247 U.S. 251 (1918). 
legislative inaction. In passing the legislation at issue here, the federal government was disagreeing with individual states' judgments and individual states' interests in favor of a perceived national interest in the prevention of child labor.

The government argued in Hammer $v$. Dagenhart that the child labor provision was necessary to equalize competition between states which had child labor laws and those which did not, because the states without child labor laws could send cheaper goods into the stream of commerce ${ }^{38}$ Therefore, in order to achieve the national interest in the prevention of child labor, it was necessary to put states which allowed child labor at a competitive disadvantage. ${ }^{30}$ To the Lochner Court this very idea was anathema: it was self-evident that the commerce clause was not designed to give Congress authority to equalize the economic advantages of some states over others. ${ }^{40}$ To permit this would be to destroy the tenth amendment guarantee of local control over the economy and turn the entire country over to a federal economic policy. ${ }^{41}$ Taking from one state and giving to another was as improper under the commerce clause as taking from one individual and giving to another was improper under the due process clause. In neither case was a legitimate public interest served.

\section{E. Assertion of Judicial Power and a High Level of Judicial Scrutiny}

Because of the Court's ideological concern with protecting economic individualism, it was willing to assert its authority to strike down state and federal economic regulations which it believed overstepped the bounds of either the due process clause or commerce clause. The Court's exercise of antimajoritarian judicial authority is the characteristic most often associated with the Lochner era.

The Court's assertion of judicial power took two forms. First, the Court operated under the assumption that it possessed the authority and the compe-

38. Id. at 273.

39. Id.

40. Id.

41. Id. at 273-74. Interestingly, the Court's decision in Hammer v. Dagenhart created economic incentives for each state to adopt a policy that permitted child labor. Consider the fact that some states, like Massachusetts and New York, already had passed progressive child labor laws, and that there was competition between, say, textiles produced in these Northern states and textiles produced in Southern states like North Carolina, which had no such restrictions. Since the Court had taken the position that the federal government could not prohibit the interstate shipment of articles produced by child labor, Massachusetts and New York textile factory owners would suffer a competitive disadvantage in their very own state, for Southern textile manufacturers could undersell them. On the other hand, Massachusetts and New York would not be able to pass statutes prohibiting the importation of such articles of commerce into their own states because the attempt would be seen as favoritism for state industry; statutes of this nature would themselves violate the commerce clause. As a consequence, the Court's championing of the tenth amendment served to benefit states that adopted an individualist economic policy at the expense of those states that did not. 
tence to override legislative judgments in the field of economic regulation. This is implicit in the Court's practices, although the Court probably saw its own role as simply determining whether economic regulations were consistent with the Constitution. Second, the Court applied a high level of judicial scrutiny to the ends justifying a particular legislative measure (i.e., whether the purpose was a legitimate one) and to the means adopted to achieve the goal. Often the Court held that the abridgment of freedom of contract was not necessary to achieve the stated purposes of the leglislation. ${ }^{22}$ Thus, for example, in Lochner itself, the Court refused to acknowledge that maximum hour laws for bakers could be justified on grounds of public safety, because, in the Court's view, the regulation of the hours of bakers was unnecessary to protect the public's health. ${ }^{43}$

A high level of judicial scrutiny is often a means of allowing the Court to smoke out unconstitutional motivation, or to correct a political process which has gone awry. The Lochner Court saw the federal and state governments of its time as dominated by unscrupulous legislators who had succumbed to political pressure from the masses to adopt popular measures redistributing income from the wealthier classes. ${ }^{44}$ It was therefore necessary for the Court to protect the constitutional right of freedom of contract from majoritarian tyranny.

The Court regularly struck down statutes if it believed that the reason asserted for the legislation was a mere pretext for a redistributive motive. This is clear in Coppage v. Kansas ${ }^{46}$ and in Lochner itself. ${ }^{46}$ In the commerce clause

42. Lochner, 198 U.S. at 57-62. We normally think of an inquiry into "less restrictive alternatives" as applying only to the analysis of first amendment law. In fact, such an inquiry is a characteristic feature of any higher level of judicial scrutiny, regardless of the substantive right involved. Courts engage in this sort of analysis all the time, although they may not label it explicitly as a "less restrictive alternative" analysis. In the Lochner era, the Court often argued that restrictions on freedom of contract were unnecessarily broad, or that the public purposes stated for the regulation could be achieved in other ways. E.g., Jay Burns Baking Co. v. Bryan, 264 U.S. 504, 517 (1924) (state law requiring standardized weights for loaves of bread unnecessary to achieve purpose of preventing consumer fraud when less restrictive means could have been employed); Adkins v. Children's Hosp., 261 U.S. 525, 546-48 (1923) (minimum wage regulation for women had too broad a coverage; regulation necessary only in limited areas of industry).

43. The Court acted as its own judge of the necessity of the regulation, and therefore utilized its own stereotypes of human relations in determining the relation of legislative means to legislative ends. The Court could sometimes be persuaded with factual evidence, if such evidence reinforced its stereotypes; the most famous example is the "Brandeis Brief" in Muller v. Oregon, 208 U.S. 412 (1908), which helped to convince the Court to uphold a maximum hour provision for women, on the grounds that long hours might interfere with maternal health and well-being. On the other hand, the Court was not always willing to be educated out of its preconcieved ideas about economic and social relationships. When confronted with a similar "Brandeis Brief" in Adkins v. Children's Hosp., 261 U.S. at 559-60, the Court found the factual assertions "interesting but only mildly persuasive." Id. at 560 .

44. E.g., Lochner, 198 U.S. at 64 ("It is impossible for us to shut our eyes to the fact that many of the laws of this character, while passed under what is claimed to be the police power for the purpose of protecting the public health or welfare, are, in reality, passed for other motives.").

45. 236 U.S. at 15-18.

46. 198 U.S. at $63-64$. 
cases, the Court relied on Chief Justice Marshall's dictum in McCulloch $v . M a-$ ryland ${ }^{47}$ that if Congress passes a law apparently within its powers as a pretext for achieving a purpose beyond its powers, the Court must strike the statute down. ${ }^{48}$ Thus, in Hammer $v$. Dagenhart, the Court saw the federal ban on child labor as essentially achieving, through a regulation of interstate commerce, what the individual states had decided not to do through the exercise of their police powers. ${ }^{49}$ Since these police powers were reserved to the states, a federal regulation of commerce whose "real" purpose was to regulate local commerce in a way a state had not chosen violated the tenth amendment."0

\section{THE COUNTER-IDEOLOGY OF THE POST-1937 ERA}

With the decline of Lochner and the establishment of a new majority on the Supreme Court, there was an ideological revolution in judicial review of economic regulation. A new counter-ideology emerged as each of the features of Lochner jurisprudence was replaced by an opposite orientation: (1) a rejection of economic individualism in favor of market regulation; (2) a preference for uniform federal regulation as opposed to state and local regulation; (3) an anticonceptualist or pragmatic approach to problems of economic regulation; (4) the decline of the public/private distinction; and (5) a low level of judicial scrutiny and an assertion of legislative competence and authority in matters concerning economic regulation. Each of these features will now be discussed in turn.

\section{A. The Rejection of Economic Individualism in Favor of Market Regulation}

The Court's conceptual framework in substantive due process cases had already begun to break down in the late 1920s and early 1930s. ${ }^{51}$ At the same time, the Court's commerce clause opinions began to show signs of intellectual strain. The death knell of the old ideology, however, was sounded by the Great Depression. The Great Depression was a cogent argument against economic

47. 17 U.S. (4 Wheat) 316 (1819).

48. Id. at 423.

49. 247 U.S. at 275-76.

50. Id. Shortly after Hammer v. Dagenhart was decided, Congress tried to achieve the same effect through the use of its taxing powers (art. I, § 8), by imposing a federal excise tax of $10 \%$ of annual net profits from businesses which used child labor. In Bailey v. Drexel Furniture Co. (The Child Labor Tax Case), 259 U.S. 20 (1922), the Court struck this down as an impermissible use of the taxing power. The reasoning behind the Court's opinion was that the tax was really not a revenue raising device but was really a penalty. $I d$. at $36-38$. Taxes normally are regulatory as well as revenue raising devices, but the Court saw the legislation as an attempt to overrule its decision in Hammer $v$. Dagenhart and thus an attack on state regulatory sovereignty protected by the tenth amendment. Id. at 39.

51. See, e.g., Nebbia v. New York, 291 U.S. 502 (1934); Miller v. Schoene, 276 U.S. 272 (1928); Pennsylvania Coal Co. v. Mahon, 260 U.S. 393 (1922). See generally L. Tribe, Amrrican ConstituTIONAL LAW $\S 8-5$, at $442-46$ (1978). 
individualism and the decentralization of economic power. The new Justices appointed by President Roosevelt were quite willing to allow the states and the federal government to regulate the free market in the public interest. This new philosophy I will call economic communalism.

Communalism is the philosophy which affirms the responsibility that persons have to each other for their actions, and which emphasizes the interdependence of actors in society. ${ }^{82}$ The new communalist ideology recognized the systemic nature of economic problems and the need for governmental intervention to correct deficiencies in market outcomes or other forms of market failure. In contrast to economic individualism, economic communalism rejected the claim that the relentless pursuit of each individual's self-interest, without concern for the effects on others, would necessarily lead to the best results for society. The employer's use of his superior bargaining power to reduce employees' wages and increase their hours might not maximize social welfare but simply perpetuate poverty; cutthroat competition among farmers in a depressed market might drive all of them out of business. Thus, the new ideology asserted that regulating individual market transactions might be necessary to achieve the greatest good.

The new emphasis on civil rights and the eradication of racial discrimination in the late 1960 s is another example of the shift to economic communalism. According to the ideology of the Lochner era, a private party's right to refuse to enter into contractual relations with any person was considered the essence of liberty of contact. ${ }^{.3}$ It followed that refusals to engage in private economic transactions for racially discriminatory reasons were as protected from public regulation as refusals to enter into a contract because the other party demanded too high a wage, or was a member of a labor union. Thus the common law conception of the offeror as the master of his bargain justified private racial discrimination. Indeed, concern for freedom of association, whether economic or otherwise, may have led the Court to permit state enforced segregation; ${ }^{54}$ a contrary rule would, in effect, have forced the two races together against their will. ${ }^{\mathrm{s}}$

With the shift in ideology to economic communalism, there was greater recognition that the sum of individual refusals to engage in contracts due to racial discrimination would result in a systemic relegation of blacks to second class citizenship. ${ }^{36}$ Removing from whites the right not to contract with blacks

52. See generally Kennedy, supra note 15; Balkin, supra note 15. Kennedy's term for this philosophical idea is "altruism."

53. E.g., Adair v. United States, 208 U.S. at 172-76.

54. See, e.g., Plessy v. Ferguson, 163 U.S. 537 (1896).

55. See id. at 551. At the same time one could argue that state enforced separation of the races violated the freedom of contract of blacks and whites who wished to associate with each other. Id. at 557 (Harlan, J., dissenting). Apparently (and perhaps for other reasons), this argument was lost on the Justices who joined in the majority opinion.

56. E.g., Katzenbach v. McClung, 379 U.S. 294, 299-300 (1964) (relying on Congressional findings of widespread discriminatory practices). 
clearly resulted in an abridgement of the freedom of contract of white individuals and a shift of power to minorities. This purpose would have been considered beyond the powers of either the states or the federal government in the Lochner era. However, the regulation of individual contractual relations to achieve the societal goal of racial justice was in perfect harmony with a theory of economic communalism. ${ }^{\text {st }}$

\section{B. The Preference for Federal Regulatory Power over State Power}

Just as there is a connection between economic individualism and a preference for state regulation over federal regulation, there is a connection between economic communalism and a preference for uniform national regulation of the economy. The Great Depression had demonstrated how interdependent all the different parts of the nation's economy were to each other. Moreover, it became apparent that separately the states were unable to effect the kind of nationwide solutions to economic problems that the Great Depression seemed to require. ${ }^{\mathrm{s}}$ To critics of the Lochner Court, the insistence that states and localities should be free to solve their economic problems in the face of a national economic disaster was as much of a cruel joke as the insistence that the Court would protect equally the freedom of contract of an unemployed worker and the owner of a factory. Both doctrinal stances seemed to breathe an air of unreality given the serious economic crisis that the country faced at that point.

Thus the movement towards market regulation, which worked a removal of economic power from individual decision makers to the government, was accompanied by a movement from the primacy of state economic regulation to that of federal economic regulation. The new emphasis on federal regulatory power left the tenth amendment with much the same importance that the due process clause now had in matters of economic regulation; that is to say, it left it with hardly any importance at all. In United States $v$. Carolene Products ${ }^{58}$ and its progeny, the Supreme Court relegated the due process clause to a source of protection from only the most irrational governmental regulations of economic freedom. ${ }^{60}$ In United States $v$. Darby, ${ }^{61}$ the Court converted the language of the tenth amendment into a mere truism: that what the states have not surrendered, they retain. ${ }^{62}$ The decline of economic due process as the protector of economic individualism went hand-in-hand with the decline of the importance of the tenth amendment as the protector of state and local authority in economic regulation.

57. See, e.g., id.; Heart of Atlanta Motel v. United States, 379 U.S. 241 (1964).

58. See, e.g., Carter, 298 U.S. at 330-32 (Cardozo, J., dissenting); Jones \& Laughlin Steel Corp., 301 U.S. at 43.

59. 304 U.S. 144 (1938).

60. 304 U.S. at 152-54; see also United States R. R. Retirement Bd. v. Fritz, 449 U.S. 166 (1980); Dandridge v. Williams, 397 U.S. 471 (1970); Ferguson v. Skrupa, 372 U.S. 726 (1963).

61. 312 U.S. 100 (1941).

62. Id. at 123-24. 


\section{Nonconceptualist Approaches to Economic Regulation}

In the post-1937 era, the Court abandoned the conceptualism of Schechter Poultry Corp. v. United States ${ }^{63}$ and Carter $v$. Carter Coal Co. in favor of a more pragmatic approach to economic regulation cases. The Court recognized that local activities may have real effects on national economic health, no matter whether they are labelled "direct" or "indirect." Instead of determining Congress' powers through abstract conceptualization, the Court began to focus on the simple causal connection between local disruptions of the economy and the nation's economic health. In the same fashion, in the due process cases, the Court began to emphasize the connection between the systemic economic effects of individual contracts of employment and the public interest. ${ }^{64}$

An excellent example of the new pragmatism was $N L R B \quad v$. Jones and Laughlin Steel Corp., ${ }^{68}$ where the Court held that Congress had the ability to regulate intrastate commerce where it might cause an obstruction to the free flow of interstate commerce. ${ }^{66}$ The Court abandoned the metaphor of movement across state lines, recognizing that many types of restrictions can "obstruct" or "disrupt" interstate commerce. ${ }^{67}$ In particular, labor unrest would have ripple effects in the economy which would disrupt interstate commerce. ${ }^{68}$ The Court emphasized that Jones and Laughlin was a large multistate enterprise (it had offices in nineteen states) which was also vertically integrated; "[w]hen industries organize themselves on a national scale, making their relation to interstate commerce the dominant factor in their activities" tion of these industries by labor strife would have "immediate," possibly "catastrophic" consequences, even if they might be classified as "remote" or "indirect" under the doctrine of Carter v. Carter Coal Co. ${ }^{70}$

The new tests the Court adopted to review legislation under the commerce clause demonstrated the rejection of conceptualism in favor of a more pragmatic inquiry. Instead of the direct/indirect test, the Court now simply asked whether Congress could rationally have determined that the regulated activity had a substantial effect on interstate commerce. ${ }^{71}$

\section{Decline of the Public/Private Distinction}

A special case of the movement away from conceptualism was the Court's

63. 295 U.S. 495 (1935).

64. E.g., West Coast Hotel Co. v. Parrish, 300 U.S. 379 (1937); Nebbia v. New York, 291 U.S. 502 (1934).

65. 301 U.S. 1 (1937).

66. Id. at 37 .

67. Id. at $36-40$.

68. Id. at $41-43$.

69. Id. at 41 .

70. Id.

71. See United States v. Darby, 312 U.S. at 118-19; see also Heart of Atlanta Motel, 379 U.S. at 262 ("means chosen [by Congress] must be reasonably adapted to the end permitted by the Constitution"); Katzenbach, 379 U.S. at 304 (requirement of a "rational basis"). 
recognition that public interests could be served through redistributions of private economic power. This led to the collapse of the distinction, so crucial to the Lochner Court, between public (legitimate) and purely private (illegitimate) purposes for legislative enactments. From the standpoint of the new ideology, minimum wage or maximum hour legislation might alter the relative bargaining positions of employers and employees, but the shift in power was seen as permissible because it was primarily directed toward protection of the public welfare. Similarly, civil rights legislation might alter the economic power of whites vis-a-vis minorities, but that redistribution of power was considered justified by the public interest in eradicating the effects of racial discrimination.

The Court's willingness to see public purposes in governmental shifting of the economic power of private parties was taken to an extreme in Williamson v. Lee Optical Co. ${ }^{72}$ In Williamson, a strong lobby of optometrists and opthalmologists had succeeded in convincing the Oklahoma legislature to impose significant restraints on the practices of opticians. Despite the obvious private purpose of the statute, the court justified the legislation as serving public goals of consumer protection, health, and safety. ${ }^{73}$

\section{E. Legislative Competence and Authority and a Low Level of Judicial Scrutiny}

As the Court retreated from its championing of states' rights and economic individualism, it simultaneously lowered the level of judicial scrutiny it applied in economic regulation cases. There is an important connection between the substantive values that the Court thought worthy of protection and the Court's abdication of judicial authority in economic regulation cases. As pointed out above, uniform federal economic regulation was more likely than not to interfere with state regulation of local matters. Moreover, any economic regulation, whether by the federal government or the states, was likely to abridge freedom of contract. Now that the Court was no longer interested in protecting freedom of contract or state supremacy in the regulation of local matters, it was no longer interested in applying high levels of judicial scrutiny in cases involving economic regulation. Instead, the Court began to defer to legislative competence and authority in the areas of the commerce clause and economic due process.

Excellent examples of the new style of institutional argument appear in both United States $v$. Darby, ${ }^{74}$ a commerce clause opinion, and United States v. Carolene Products, ${ }^{75}$ an opinion dealing with economic due process.

In Carolene Products, the Court announced its modern test for social and economic regulation: A legislative enactment would be upheld if it was ration-

72. 348 U.S. 483 (1955).

73. $I d$.

74. 312 U.S. 100 (1941)

75. 304 U.S. 144 (1938). 
ally related to a legitimate governmental interest. ${ }^{78}$ The Court emphasized both the lack of authority and competence of an unelected judiciary to second guess the considered judgments of a legislature as to what regulations of the economy would best serve the public interest. ${ }^{77}$ Thus, the Court applied a very relaxed standard of judicial scrutiny and announced that it would accept virtually any purposes, real or hypothetical, that a legislature might offer to justify a challenged regulation. ${ }^{78}$ Equally relaxed was the Court's scrutiny of the means the legislature chose to achieve its ends. The Court no longer required the legislature to choose a means less restrictive of economic freedoms. Nor was the legislature required to regulate with precision; statutes regulating economic liberty could be overinclusive and underinclusive without failing the rational basis test, and the legislature was permitted to proceed "one step at a time" in its regulatory strategies. ${ }^{79}$

The Court justified its lower level of judicial scrutiny by emphasizing the greater authority of popularly elected legislatures to make judgments about the public interest, as well as the superior competence of legislatures to determine what social and economic regulations would benefit society. ${ }^{80}$ Thus, part and parcel of the move from the rhetoric of judicial authority and competence to the rhetoric of legislative authority and competence is the assumption that democratic processes will provide an effective means for the repeal of undesirable legislation. Faith in the democratic process was therefore essential to the new ideology; the responsiveness of legislatures to their constituents served to fill the void left when the Court abdicated its role as the protector of the public interest in economic matters. ${ }^{\text {B1 }}$

The flip side of this ideological gambit is the famous footnote four of Carolene Products. ${ }^{82}$ Where there is a failure of process, such as where there is a reason to believe that legislatures will not respond to popular will, or where there is a reason to believe that legislatures will close avenues of redress to

76. Id. at 152 .

77. Id. at 154 .

78. Id.

79. Id. at 151; see also United States R.R. Retirement Bd. v. Fritz, 449 U.S. at 179; Williamson v. Lee Optical Co., 348 U.S. at 487-89 (1955); Railway Express Agency v. New York, 336 U.S. 106, 110 (1949). The same lowered standard was applied in challenges to economic regulations under the equal protection clause. See Fritz, 449 U.S. at 174-79; San Antonio Indep. School Dist. v. Rodriguez, 411 U.S. 1 (1973); Dandridge, 397 U.S. at 483-87; Williamson, 348 U.S. at 488-89; Railway Express, 336 U.S. at 109-10; Carolene Prods., 304 U.S. at 151.

80. Carolene Prods., 304 U.S. at 152-54; see also Dandridge v. Williams, 397 U.S. at 483-87; Furgeson v. Skrupa, 372 U.S. at 730 ; Williamson, 348 U.S. at 487-88.

81. E.g., Williamson, 348 U.S. at 488:

The day is gone when this Court uses the Due Process Clause of the Fourteenth Amendment to strike down state laws, regulatory of business and industrial conditions, because they may be unwise, improvident, or out of harmony with a particular school of thought. ... "For protection against abuses by legislatures the people must resort to the polls, not to the courts."

Id. (quoting Munn v. Illinois, 94 U.S. 113, 134 (1876)).

82. 304 U.S. at 152 n.4. 
discrete and insular minorities, the Court is then justified in applying a higher level of scrutiny to legislative enactments. ${ }^{83}$ However, at the same time, Carolene Products seemed to assert as an ipse dixit that this will never be a problem where the rights and interests affected are purely economic ones.

It is instructive to stop for a second and focus on this latent assumption in the Court's new ideology: we see here the hidden connection between the substantive preference for economic communalism and the institutional rhetoric of Carolene Products. The Court is no longer interested in placing freedom of contract in the pantheon of protected liberties. Hence, it simultaneously asserts that legislation which inhibits freedom of contract (but not specially protected freedoms like speech) neither results from nor leads to a failure of political processes. This non sequitur is as important as it is unconvincing.

It should not be surprising that the same Justices who wrote these economic due process opinions also took a relaxed view of judicial scrutiny in applying the commerce clause. United States $v$. Darby is the judicial equivalent in the commerce clause area of the decision in United States $v$. Carolene Products. Interestingly enough, there is no equivalent footnote four. Footnote four was necessary to distinguish specially protected individual rights such as free expression (which justified a higher level of judicial scrutiny) from the now unprotected liberty of contract. However, in commerce clause doctrine, no distinctions are made between the types of rights that states have. Thus, United States $v$. Darby simply announces that the Court would henceforth defer to congressional judgment concerning the substantiality of the relationship between local activities and interstate commerce, ${ }^{84}$ and that there would be no judicial inquiry into the real purposes behind the regulation of local activities. ${ }^{80}$

Furthermore, just as in the due process area, the Court abandoned any "less restrictive alternative" analysis. ${ }^{86}$ In the commerce clause cases, this meant that the Court no longer required the Congress to adopt the means least destructive of state sovereignty. In Darby, for example, the Court had upheld a ban on interstate shipments of goods produced by factories not in compliance with minimum wage and maximum hour limitations. At the same time, it also permitted Congress to make it a crime to employ persons at sub-minimum

83. Id.

84. 312 U.S. at 120-21; see also Wickard v. Filburn, 317 U.S. 111, 118-125 (1942) (Congress may constitutionally apply wheat marketing quota to small amount of wheat grown wholly for consumption on farm, because of interdependence of national market and Congressional judgment that aggregate effect of small farm practices may have significant impact on national market); Heart of Atlanta Motel, 379 U.S. at 249-62 (deferring to Congressional judgment as to the aggregate effects of individual acts of racial discrimination on interstate commerce); Perez v. United States, 402 U.S. 146, 154-55 (1971) (upholding Congressional power to regulate local loan sharking practices and deferring to Congressional judgment that loan sharking activities as a class affect interstate commerce).

85. Darby, 312 U.S. at 115-17.

86. See supra note $\mathbf{4 2}$ for a discussion of the "less restrictive alternative" analysis in the Lochner era. 
wages or for longer than maximum hours in the production of goods for interstate commerce. ${ }^{87}$ Clearly, a ban on interstate transportation was less restrictive to state regulatory policies than a ban on intrastate activity; yet this was not a factor in the Court's analysis. The Court argued that since the Congress could prohibit the movement of these articles in interstate commerce, it could chose any means reasonably adapted to achieve that end, even if it involved control of purely intrastate activities. ${ }^{88}$

The post-1937 counter-ideology was remarkably successful in making judicial deference in economic regulation cases seem the norm rather than the exception. The next part of this Article describes a recent challenge to that dominant ideology - a counter-insurgency which appeared in the opinions of the conservative Burger Court in the 1970s, and most particularly in the 1976 opinion in National League of Cities.

\section{THE REVOLUTION OF 1976 - NATIONAL LEAGUE OF CITIES AND THE BURGER COURT'S NEW FEDERALISM}

After Richard Nixon placed four Justices on the Supreme Court, the Supreme Court's positions on many issues began to veer noticeably to the right. The Court began to use the rhetoric of modern conservatism in its opinions: it emphasized the importance of states' rights and deference to government officials, especially state or local government officials. ${ }^{82}$ The Burger Court became increasingly fond of statements that the federal courts should not be interfering with local decision making by police departments, state employers, state prisons, state mental hospitals, or other state officials. ${ }^{80}$

Part of the explanation for this new rhetoric was a concern that the Warren Court had gone too far in expansion of the rights of criminal defendants and minorities. Another concern was the increasing resort to the federal courts by public interest groups as means of redressing social wrongs. When federal courts discovered constitutional violations of a systemic nature, they used their injunctive powers for wide-ranging supervision of state and local decision makers. ${ }^{91}$ The spectre of a federal district judge overseeing the day-to-day opera-

87. Id. at 117-24.

88. Id. at 121 .

89. E.g., Los Angeles v. Lyons, 461 U.S. 95 (1983); Ingraham v. Wright, 430 U.S. 651 (1977); Meachum v. Fano, 427 U.S. 215 (1976); Rizzo v. Goode, 423 U.S. 362 (1976); Bishop v. Wood, 426 U.S. 341 (1976); Huffman v. Pursue, Ltd., 420 U.S. 592 (1975); O'Shea v. Littleton, 414 U.S. 488 (1974); Wolff v. McDonnell, 418 U.S. 539 (1974); Younger v. Harris, 401 U.S. 37 (1971).

90. E.g., Los Angeles v. Lyons, 461 U.S. at 112 ("[R]ecognition of the need for a proper balance between state and federal authority counsels restraint in the issuance of injunctions against state officers engaged in the administration of the States' criminal laws . . . .); Warth v. Seldin, 422 U.S. 490,508 n. 18 (1975) ("We ... note that zoning laws and their provisions, long considered essential to effective urban planning, are peculiarly within the province of state and local legislative authorities."). See generally Weinberg, The New Judicial Federalism, 29 STAN. L. REV. 1191 (1977).

91. E.g., Council of Orgs. on Philadelphia Police Accountability and Responsibility v. Rizzo, 357 F. Supp. 1289 (E.D. Pa. 1973), aff'd, Goode v. Rizzo, 506 F.2d 542 (3d Cir. 1974), rev'd, Rizzo 
tions of a state prison system, a state mental institution, a city police department or a local school district greatly troubled the new conservative majority on the Supreme Court. As explained above, conservative ideology sees a deep connection between the decentralization of power from governmental authority to individual rights and the decentralization of power from national decision making to state or local decision making. The notion of a federal court supervising the day-to-day administration of a state institution was therefore anathema to the new Burger Court majority.

The new mood in the Supreme Court was that the federal government had too much control over state governmental functions. The Supreme Court was able to restrict federal judicial power by manipulating doctrines of standing and justiciability to cut back on civil rights lawsuits, ${ }^{92}$ and also by narrowly construing the reach and effect of federal civil rights legislation and constitutional provisions..$^{93}$ However, the Court also wanted to strike a blow for states' rights in opposition to the powers of Congress. National League of Cities, then, was part of the Burger Court's holy war against the lingering forces of bankrupt liberalism and big government. It is not an exaggeration to compare the decision to the opening salvo in a war. Indeed, in Garcia itself, Justice O'Connor's dissent uses an identical metaphor: "The Court . . . surveys the battle scene of federalism and sounds a retreat . . . I would prefer to hold the field and, at the very least, render a little aid to the wounded."

\section{A. The Ideology of National League of Cities}

It is important to note at the outset that National League of Cities was not a wholesale return to Lochner era jurisprudence. There is a significant difference between the doctrinal goals of the Lochner Court and the goals of the Burger Court. The Lochner Court argued that the federal government's power to regulate purely private economic transactions was limited by the tenth amendment's guarantee of state sovereignty. The Burger Court was not about

v. Goode, 423 U.S. 362 (1976).

92. E.g., Los Angeles v. Lyons, 461 U.S. 95 (1983); Valley Forge Christian College v. Americans United for Separation of Church and State, Inc., 454 U.S. 464 (1982); Rizzo v. Goode, 423 U.S. 362 (1976); Simon v. Eastern Ky. Welfare Rights Org., 426 U.S. 26 (1976); Warth v. Seldin, 422 U.S. 490 (1975); United States v. Richardson, 418 U.S. 166 (1974); Schlesinger v. Reservists Committee to Stop the War, 418 U.S. 208 (1974); Broadrick v. Oklahoma, 413 U.S. 601 (1973); Laird v. Tatum, 408 U.S. 1 (1972).

93. E.g., Paul v. Davis, 424 U.S. 693 (1976) (requiring that action for injury to reputation by a state official to be brought in state courts as common law defamation action); Ingraham v. Wright, 430 U.S. 651 (1977)(holding that eighth amendment does not protect students from wrongful corporal punishment and requring students to sue in state court under common law action for battery); Parratt v. Taylor, 451 U.S. 527 (1981)(requiring that claims of negligent deprivation of property by state officials be brought in state court if a state law remedy is available); Pennhurst State School and Hosp. v. Halderman, 451 U.S. 1 (1980)(narrowly construing right of action); Middlesex County Sewerage Auth. v. National Sea Clammers Ass'n., 453 U.S. 1 (1981)(narrowly construing phrase "and laws" in 42 U.S.C. § 1983).

94. Garcia, 105 S. Ct. at 1033. 
to fight again the battle that had already been lost in United States $v$. Darby. Justice Rehnquist's goal in National League of Cities was more limited in scope, at least in its initial incarnation. His idea was to prevent the federal government from using its commerce clause powers to regulate state governmental functions, as opposed to regulating private local activities within a state. $^{95}$ The Court did not doubt that Congressional power under the commerce clause was plenary within its sphere; it acknowledged that Congress could regulate purely local economic activity if such activity affected interstate commerce. ${ }^{96}$ Rather, the point of National League of Cities was that the tenth amendment carved out little islands of state immunity from otherwise permissible federal regulation, when the federal regulation touched upon sensitive areas of state sovereignty.

Although the goals of the Burger Court in National League of Cities were more modest than those of the Lochner Court, the opinion in National League of Cities did share many common features with the decisions of that era. However, those similarities are not doctrinal. They are ideological. The types of argument used by the Court in National League of Cities recall the ideology of the Lochner era, while the types of argument used by the Court in Garcia reaffirm the dominant counter-ideology of the post-1937 era.

What is especially fascinating about the line of cases from National League of Cities to Garcia is that the clash of ideologies takes place in a narrowly defined battleground. The issue is no longer the states' ability to regulate the local economy as a whole but only the states' ability to regulate their own governmental functions contrary to uniform federal economic regulation. Nevertheless, the rhetorical gestures of the pre- and post-1937 ideology reappear in new disguises. Thus, in a very real sense, National League of Cities resembled a border skirmish in a larger war that had been lost long ago.

The next part of this Article demonstrates how each of the components of Lochner jurisprudence reappeared in a more limited form in the majority opinion in National League of Cities, and in the dissenting opinions of the cases that followed it.

\section{B. National League of Cities and the Decentralization of Economic Regulatory Power}

It would be a gross oversimplification to see National League of Cities as an attempt to reestablish the Lochner era's judicial protection of freedom of contract. At the same time, Justice Rehnquist's majority opinion manifested a hostility to centralized federal control of economic decision making, and a preference for free market solutions to economic problems. It was no accident that National League of Cities involved the constitutionality of minimum wage and maximum hour laws. These were the same types of regulations that the Lochner court delighted in striking down in the name of freedom of contract and

95. 426 U.S. at 845 .

96. Id. at 840 . 
state regulatory authority ${ }^{97}$ It was also no accident that in arguing against the application of these laws to state and local employees, Justice Rehnquist made a standard individualist argument against economic regulation; by interfering with the market forces of supply and demand, economic regulations will in the long run hurt the very people they were designed to protect. State and local employers will hire fewer employees, offer fewer services to the public, the cost of services provided will increase, and limited resources will be diverted in an inefficient manner. ${ }^{88}$ In any case, such regulations reduce the choices otherwise available to state and local governments in how they will spend their money:

The State might wish to employ persons with little or no training, or those who wish to work on a casual basis, or those who for some other reason do not possess minimum employment requirements, and pay them less than the federally prescribed minimum wage. It may wish to offer part-time or summer employment to teenagers at a figure less than the minimum wage, and if unable to do so may decline to offer such employment at all.99

Consistent with a bias in favor of economic individualism, the four conservative justices in the National League of Cities majority ${ }^{100}$ also opposed the application of the federal Age Discrimination in Employment Act (ADEA) to state employees. ${ }^{101}$ As explained above, anti-discrimination laws abridge the freedom of the employer to choose who the employer will and will not contract with. In his dissenting opinion in EEOC $v$. Wyoming, Chief Justice Burger rejected claims that he was arguing for a state's "right to discriminate" on the

97. National League of Cities considered the constitutionality of the 1974 amendments to the 1938 Fair Labor Standards Act. The amendments extended the wage and hour provisions of the Act to state and local governmental employees. The wage and hour provisions were held constitutional as to private employers in United States v. Darby, 312 U.S. 100 (1941), which overruled Hammer v. Dagenhart, 247 U.S. 251 (1918).

98. 426 U.S. at 848; see also EEOC v. Wyoming, 460 U.S. 226, 255-56 (1983) (Burger, C.J., dissenting):

It is beyond dispute that the [Federal Age Discrimination in Employment Act] can give rise to increased employment costs caused by forced employment of older individuals. Since these employees tend to be at the upper end of the pay scale, the cost of their wages while they are still in the work force is greater . . . . [P]ension costs are greater when an older employee retires. The employer is also forced to pay more for insuring the health of older employees ... [and] it is reasonable to conclude that the employer's disability costs are increased.

....

Since older workers occupy a disproportionate share of the upper-level and supervisory positions, a bar on mandatory retirement also impedes promotion opportunities . . . [which] tends to undermine younger employees' incentive to strive for excellence . . . . 99. 426 U.S. at 848.

100. Chief Justice Burger, Justice Powell, Justice Stewart and Justice Rehnquist were in the original five person majority. Justice O'Connor replaced Justice Stewart and continued to vote with the conservatives in succeeding cases. Justice Blackmun orignally sided with these justices but voted with the National League of Cities dissenters in succeeding cases and authored the opinion in Garcia, overruling National League of Cities.

101. EEOC v. W.yoming, 460 U.S. 226 (1983). 
basis of age. ${ }^{102}$ However, his arguments bear a remarkable similarity to a standard freedom of contract justification; because of the application of the ADEA to state and local governments, Wyoming as an employer is forbidden to employ persons it thinks best able to do the job on terms it chooses.

Of course, the freedom of contract argument in these cases does not refer to the freedom of contract of individuals. That is because National League of Cities involved an ideological struggle focused on a limited area; the area of a state's regulation of its own governmental operations. Indeed, the freedom of contract argument was all the more powerful because it was allied with notions of state sovereignty. As Justice Rehnquist put it:

[The problems] presented by . . . minimum wage restrictions may seem not immediately different from that faced by private employers, who have long been covered by the Act and who must find ways to increase their gross income if they are to pay higher wages while maintaining current earnings. The difference, however, is that a State is not merely a factor in the "shifting economic arrangements" of the private sector of the economy, . . . but is itself a coordinate element in the system established by the Framers for governing our Federal Union. ${ }^{10 s}$

Thus, to be more precise, National League of Cities represented a preference for "State freedom of contract." This was not an isolated development. In the same term that National League of Cities was decided, the Court held in Hughes $v$. Alexandria Scrap Corp. ${ }^{104}$ that where a state acts as market participant (i.e., as a contracting party) and not as a market regulator, the implied restrictions of the commerce clause do not apply to it. ${ }^{105}$ The rationale for this distinction again combined aspects of state sovereignty and freedom of contract. $^{106}$

102. Id. at 259 .

103. 426 U.S at $848-49$.

104. 426 U.S. 794 (1976).

105. Id. at 810; see also White v. Massachusetts Council of Const. Employers, 460 U.S. 204, 214-15 (1983); Reeves, Inc. v. Stake, 447 U.S. 429, 436-37 (1980).

106. E.g., Reeves, Inc. v. Stake, 447 U.S. at $438-39$ :

[The market participant exception] is counseled by considerations of state sovereignty, the role of each State "as guardian and trustee for its people," . . . and "the long recognized right of trader or manufacturer, engaged in an entirely private business, freely to exercise his own independent discretion as to parties with whom he will deal."

Id. (quoting Heim v. McCall, 239 U.S. 175, 191 (1915) and United States v. Colgate \& Co., 250 U.S. 300,307 (1919)). In a footnote accompanying the above, the Court added:

Considerations of sovereignty independently dictate that marketplace actions involving "integral operations in areas of traditional governmental functions" - such as the employment of certain state workers - may not be subject even to congressional regulation persuant to the commerce power. National League of Cities $v$. Usery, 426 U.S. 833, 852 (1976). It follows easily that the intrinsic limits of the Commerce Clause do not prohibit state marketplace conduct that falls within this sphere. Even where "integral operations" are not implicated, States may fairly claim some measure of a sovereign interest in retaining freedom to decide how, with whom, and for whose benefit to deal. The Supreme Court, 1975 Term, 90 Harv. L. REv. 1, 56, 63 (1976). 


\section{State Regulatory Power Preferred to Federal}

An essential element of National League of Cities jurisprudence, then, was the assertion of the right of states to have their sovereignty protected from federal usurpation. Like the Lochner Court before it, the majority in National League of Cities stressed the special place of the states in the constitutional scheme. ${ }^{107}$ At the same time, the Court in National League of Cities emphasized that the federal government's power to impose uniform economic regulation was limited. This too, recalls the rhetoric of the Lochner Court. One need only compare the following excerpts to see that the forms of argument are identical, even though the area of contention has changed;

\section{Hammer v. Dagenhart:}

The power of the States to regulate their purely internal affairs by such laws as seem wise to the local authority is inherent and has never been surrendered to the general government.

...

[I]f Congress can thus regulate matters entrusted to local authority by prohibition of the movement of commodities in interstate commerce, all freedom of commerce will be at an end, and the power of the States over local matters may be eliminated, and thus our system of government be practically destroyed. ${ }^{108}$

\section{National League of Cities:}

[T] he minimum wage and the maximum hour provisions will impermissibly interfere with the integral governmental functions of [the States] . . . [I]t is functions such as these which governments are created to provide, services such as these which the States have traditionally afforded their citizens. If Congress may withdraw from the States the authority to make those fundamental employment decisions upon which their systems for performance of these functions must rest, we think there would be little left of the States' "separate and independent existence." 100

As noted above, the Lochner ideology saw a connection between a preference for state's rights and state regulatory power, on the one hand, and decentralization of power and individual freedom on the other. This connection is also evident in the ideology of National League of Cities; uniform regulation of integral state functions removes power from state and local governments, which are thought to be more responsive to local interests and concerns. A good example of this rhetoric appears in Justice O'Connor's partial dissent in

\section{Id. at 438 n. 10.}

107. 426 U.S. at 844; see also EEOC v. Wyoming, 460 U.S. at 265-75 (Powell, J. dissenting). Powell's dissent in this case, along with his dissent in Garcia, are eloquent modern statements of the pro-state sovereignty position. See also FERC v. Mississippi, 456 U.S. 742, $787-87$ (1982) ( $O^{\prime}$ Connor, J., concurring in the judgment in part and dissenting in part).

108. 247 U.S. at 275-76.

109. 426 U.S. at 851. 
FERC $v$. Mississippi. ${ }^{110}$ In FERC, the Court upheld the constitutionality of the Public Utility Regulatory Policies Act of 1978 (PURPA). ${ }^{11}$ Titles I and III of PURPA required state utility regulatory commissions and nonregulated utilities to consider the adoption and implementation of specific federally created regulatory standards, and required state commissioners to follow certain notice and comment proceedures when acting on the proposed federal standards. The majority argued that PURPA only required the states to consider federal regulatory standards or cease regulating in the affected area (electricity and gas utility regulation). ${ }^{112}$ For this reason, the majority claimed that PURPA was less intrusive on state sovereignty than complete preemption, which would have clearly been permissible under the tenth amendment.11s

Justice O'Connor's partial dissent protested that PURPA "conscript[ed] state utility commissions into the national bureaucratic army."114 The rhetoric of her opinion reflects the conservative identification of uniform federal regulation with a loss of individual influence in governmental decisions and a concomitant loss in the individual's support of and identification with governmental decision making:

Local citizens hold their utility commmissions accountable for the choices they make $\therefore$. . Congressional compulsion of state agencies, unlike pre-emption, blurs the lines of political accountability and leaves citizens feeling that their representatives are no longer responsive to local needs.

...

In addition to promoting experimentation, federalism enhances the opportunity of all citizens to participate in representative government . . . . Citizens ... cannot learn the lessons of self-government if their local efforts are devoted to reviewing proposals formulated by a faraway national legislature. If we want to preserve the ability of citizens to learn democratic processes through participation in local government, citizens must retain the power to govern, not merely administer, their local problems.

Finally, our federal system provides a salutary check on governmental power. As Justice Harlan once explained, our ancestors "were suspicious of every form of all-powerful central authority ...." To curb this evil, the founding fathers both allocated governmental power between state and national authorities, and divided the national power among three branches of government. Unless we zealously protect these distinctions, we risk upsetting

110. 456 U.S. 742 (1982). Justice O'Connor's opinion was joined by the Chief Justice and Justice Rehnquist. Justice Powell also filed a partial dissent. Therefore, in $F E R C$, the conservative votes lined up in the same way as in National League of Cities, EEOC $v$. Wyoming and Garcia, with Justice O'Connor substituting for Justice Stewart in the last two cases. The five person majority in FERC was the same as that in EEOC $v$. Wyoming and Garcia; that is to say, it consisted of the National League of Cities dissenters plus Justice Blackmun, who wrote the majority opinion in FERC.

111. Pub. L. No. 95-617, 92 Stat. 3117.

112. FERC v. Mississippi, 456 U.S. at 764.

113. Id, at 764-65.

114. Id. at 775 (O'Connor, J., concurring in the judgment in part and dissenting in part). 
the balance of power that buttresses our basic liberties. ${ }^{115}$

\section{The Public/Private Distinction and the Limited Conceptualism of National League of Cities and its Progeny}

There is an obvious tension between the expansive view of the scope of the federal commerce power and the notions of state sovereignty embodied in $\mathrm{Na}$ tional League of Cities. As Justice Brennan pointed out in his dissent in $\mathrm{Na}$ tional League of Cities, the majority had to concede that the federal government could preempt an entire area of state regulation by its actions. ${ }^{116}$ If anything violated a state's decision making discretion, complete preemption would; preemption is an order to the states that certain regulatory choices are foreclosed to them. Moreover, as Justice Stevens pointed out in his dissent in National League of Cities, there is no reason why the federal government cannot require state employees to pay social security taxes or abide by other types of federal regulations (i.e., anti-pollution regulations, federally mandated safety regulations, federally mandated speed limits, and so forth). ${ }^{117}$ Indeed, if the Occupational Safety and Health Administration issued regulations stating that asbestos could not be used in office buildings with more than five employees, it would be hard to argue that a state capitol building would be exempted. ${ }^{118}$

In order to justify the islands of state regulatory immunity created by the tenth amendment, and to distinguish them from activities that were subject to uniform federal regulation, the National League of Cities majority had to reestablish a limited form of conceptualism in economic regulation cases, namely, the public/private distinction. According to Justice Rehnquist, the fact that a federal regulation forecloses a regulatory choice is not enough to invoke the protections of the tenth amendment. Rather, regulatory immunity exists

115. Id. at 787-790 (quoting Harlan, Thoughts at a Dedication: Keeping the Judicial Function in Balance, 49 A.B.A. J. 943, 944 (1963)). Justice O'Connor also argued that federalism promoted innovative legislation by state and local governments:

Courts and commentators frequently have recognized that the 50 States serve as laboratories for the development of new social, economic, and political ideas . . . PURPA, which commands state agencies to spend their time evaluating federally proposed standards and defending their decisions to adopt or reject those standards, will retard this creative experimentation.

Id. at 788-89. In support of her claim, Justice O'Connor cited Justice Brandeis' famous dissent in New State Ice Co. v. Liebmann, 285 U.S. 262, 311 (1932). FERC v. Mississippi, 456 U.S. at 788 n. 20. There is a certain irony to Justice O'Connor's choice of authority. In Liebmann, Justice Brandeis supported federalist principles in order to argue against the Lochner Court's assertion of federal judicial authority to invalidate progressive state legislation. In $F E R C$, Justice O'Connor makes a federalism argument to defend federal judicial authority to invalidate federal economic legislation passed by a democratically elected body.

116. National League of Cities, 426 U.S. at 875 (Brennan, J., dissenting).

117. Id. at 880-81 (Stevens, J., dissenting).

118. But cf. Coyle v. Oklahoma, 221 U.S. 559, 565 (1911) (Congress may not displace states' powers to establish a location for the state capitol or interfere with the appropriation of funds for that purpose). 
only when the federal regulation "displace[s] the States' freedom to structure integral operations in areas of traditional functions,"119 or impairs an "attribute of state sovereignty." 120 By the time of the Court's unanimous decision in Hodel v. Virginia Surface Mining \& Reclamation Association, ${ }^{121}$ the Court had established a three part test: (1) the challenged regulation had to regulate the states as states; (2) the federal regulation had to address matters that were indisputably attributes of state sovereignty; and (3) it must be apparent that the states' compliance with the federal law would directly impair their ability to structure integral operations in areas of traditional governmental functions. ${ }^{122}$

I do not claim that either Rehnquist's remarks about "integral operations" or "attributes of state sovereignty" in National League of Cities or the three part test of Hodel were identical to the old-fashioned common-law inspired abstractions of the Lochner era. ${ }^{123}$ Just as National League of Cities did not represent a wholesale return to freedom of contract in the private sphere, but only a limited reassertion of economic individualism as "State freedom of contract," so too the conceptualist moves in National League of Cities and its progeny were of a limited nature. Rehnquist's opinion in National League of Cities is conceptualist in the sense that it sees clearly demarcated and exclusive spheres of state sovereignty, as opposed to a vision balancing conflicting federal and state interests (which Justice Blackmun argued for his concurring opinion in National League of Cities). Still, if Rehnquist's position was conceptualist at all, it reflected a watered-down conceptualism.

On the other hand, the tests established in National League of Cities and Hodel do constitute a latter day resurrection of the public/private distinction, a distinction which was intimately related to the Lochner Court's conceptualist (and individualist) jurisprudence. Although the federal government possessed plenary authority to preempt state regulation of purely private, local activities, the governmental decisions and functions of the "States as States" were immune from federal regulatory power.

The continued validity of the public/private distinction was an essential

119. National League of Cities, 426 U.S. at 852.

120. Id. at 845 .

121. 452 U.S. 264 (1981).

122. Id. at 287-88. The Court also added that if each of these three factors were met, the Court would then balance the competing federal and state interests. Id. at $288 \mathrm{n}$. 29 . This additional requirement was tacked on at the request of Justice Blackmun, who had concurred in the 54 decision in National League of Cities on the understanding that the Court would balance state and federal interests. This balancing test was foreign to the conceptualist principles announced by Justice Rehnquist in National League of Cities itself, since the federal government had no authority to intrude upon integral state functions, no matter how great the federal interest. See infra text accompanying notes 151-153.

123. But see National League of Cities, 426 U.S. at 860 (Brennan, J., dissenting) ("My Brethren thus have today manufactured an abstraction without substance, founded neither upon the words of the Constitution nor on precedent"); id. at 867-68 ("ill-conceived abstraction" resembles the work of the Court during the Lochner era). 
postulate of the new theory of intergovernmental regulatory immunity, as Justice Rehnquist made clear enough in National League of Cities itself:

It is one thing to recognize the authority of Congress to enact laws regulating individual businesses necessarily subject to the dual sovereignty of the government of the Nation and of the State in which they reside. It is quite another to uphold a similar exercise of congressional authority directed, not to private citizens, but to the States as States. ${ }^{194}$

As detailed in Garcia, lower federal courts faced enormous problems in deciding which types of state activities were "attributes of state sovereignty" under the Hodel test and which were not. ${ }^{128}$ In United Transportation Union $v$. Long Island Rail Road Co., ${ }^{126}$ the Court tried to avoid these difficulties by distinguishing between traditional and nontraditional governmental functions. The former, but not the latter, represented the sphere of state regulatory immunity. ${ }^{127}$ However, the move to traditional/nontraditional analysis was shortlived. In the Long Island opinion itself, the Court explained that the inquiry into whether a governmental function was "traditional" or "nontraditional" "was not meant to impose a static historical view of state functions generally immune from federal regulation. Rather, it was meant to require an inquiry into whether the federal regulation affects basic state prerogatives . . .."128 Thus, the historical test did not really free the Court from the quasi-conceptualist approach necessitated by the public/private distinction.

In fact, as Blackmun argued in his opinion in Garcia, the test of National League of Cities, as subsequently developed in Hodel, was reminiscent of the governmental/proprietary distinction that the court had developed as a test of state immunity from federal taxation. ${ }^{12 \theta}$ The governmental/proprietary test was itself developed during the Lochner era $^{130}$ and reflects both the era's conceptualist approach and its reliance on the public/private distinction. When the state government acted as sovereign, its acts were those of a public body, and it was immune from federal taxation. When it acted in a proprietary capacity, it was in the same situation as a private person and the intergovernmental tax immunity did not apply. ${ }^{131}$ This distinction proved to be unworkable and was overruled in New York $v$. United States, ${ }^{132}$ a decision of the post1937 era. Thus, Justice Blackmun's comparison of the National League of Cities test to the now rejected governmental/proprietary distinction in intergov-

124. Id. at 845.

125. Garcia, $105 \mathrm{~S}$. Ct. at 1011.

126. 455 U.S. 678 (1982).

127. Id. at $683-86$.

128. Id. at 686-87.

129. Garcia, 105 S. Ct. at 1012-13.

130. South Carolina v. United States, 199 U.S. 437 (1905), which created the distinction, was decided the same year as Lochner itself.

131. Id. at 451, 461; see Ohio v. Helvering, 292 U.S. 360, 369 (1934) ("When a state enters the market place seeking customers it divests itself of its quasi sovereignty pro tanto.").

132. 326 U.S. 572 (1946). 
ernmental tax immunity cases is simply another way of seeing the relationship between the National League of Cities analysis and a limited form of conceptualism and the public/private distinction.

The public/private distinction was necessary to the logic of National League of Cities because it explained why the doctrines espoused in United States v. Darby and its progeny did not grant Congress plenary authority to impose economic regulations on the States which it could impose on private actors. ${ }^{133}$ Nevertheless, the very distinction that supported and justified $\mathrm{Na}$ tional League of Cities also led to its demise. For while the public/private distinction legitimated the Court's judicial protection of States' rights, interestingly enough, it simultaneously created a limiting principle that prevented further encroachments into federal regulatory power.

When National League of Cities was first decided, one might have been concerned that the Court's newly discovered tenth amendment limitation of federal commerce power might later be extended to limit federal regulation of private activities in ways which were inconsistent with state policy. This fear would have been grounded upon the notion that the state's exercise of its police powers to regulate (or not to regulate) private transactions is one of the most fundamental aspects of state sovereignty. If "integral aspects of state sovereignty" were construed in this fashion, National League of Cities might well have led to a resurrection of decisions like Hammer v. Dagenhart.

The Court, however, made clear in Hodel that such fears were completely ungrounded; federal regulatory policy would preempt state regulation of private enterprise, no matter how important or how traditional the state's exercise of its police powers may have been. In Hodel itself, the Court held that the state's traditional governmental function of regulating private land use would not immunize it from federal laws regulating surface coal mining operations.

For this reason, although conservatives on the Court may have wished to return to a narrower conception of federal power to regulate private activities, National League of Cities was not a thin opening wedge to the return of decisions like Hammer $v$. Dagenhart. This is because the very Justices who may have been interested in a return to a narrower conception of the federal commerce power were the same Justices who most believed in the reality and the administrability of the public/private distinction. If the Court had wanted to

133. In doing so, however, Justice Rehnquist had to reject both Maryland v. Wirtz, 392 U.S. 183 (1968) (upholding application of wage and hour provisions of the Fair Labor Standards Act to employees of public schools and hospitals), and language in United States v. California, 297 U.S. 175, 185 (1936):

[W]e look to the activities to which the states have traditionally engaged as marking the boundary of the restriction upon the federal taxing power. But there is no such limitation upon the plenary power to regulate commerce. The State can no more deny the power if its exercise has been authorized by Congress than can an individual (upholding application of Federal Safety Appliance Act to state-owned and operated railroad).

See also Fry v. United States, 421 U.S. 542 (1975)(upholding wage-freezing provisions of the Economic Stabilization Act of 1970 as applied to state and local government employees). 
use National League of Cities to return to decisions like Hammer $v$. Dagenhart, the Court would have had to assert that state regulation of private enterprise was an integral state function; that would have undermined the very distinction that National League of Cities rested upon in the first place.

\section{E. Assertion of Judicial Power and a High Level of Judicial Scrutiny}

Applying the doctrine of National League of Cities required the Court to abandon its position of extreme deference to Congressional judgments and its low level of scrutiny in commerce clause cases where integral state functions were affected. Instead, like the Lochner Court before it, the Court adopted a higher level of scrutiny of both Congress' ends and the means Congress used to achieve those ends.

Unlike the ordinary post-Darby commerce clause case, where the Court was likely to show great deference to the congressional statement of purpose, Justice Rehnquist examined the purpose asserted by Congress as justifying the 1974 FLSA amendments, and found it lacking. This in itself is a sign that a higher level of scrutiny is being invoked. The Secretary of Commerce argued that the purpose of the $\mathbf{1 9 7 4}$ amendments was to discourage making employees work longer hours than Congress thought desirable. Justice Rehnquist stated that although "[i]t may well be that as a matter of economic policy it would be desirable that States, just as private employers, comply with . . minimum wage requirements," "sist the federal government could not act with the purpose of "displac[ing] state policies regarding the manner in which [states] will structure delivery of those governmental services which their citizens require,"1s6 or "supplant[ing] the considered policy choices of the States' elected officials and administrators as to how they wish to structure pay scales in state employment."138 In sum, Congress did not have the power to impose uniformity in minimum wages and maximum hours simply because Congress disagreed with nonconforming state policies. "Correcting" state regulatory choices which deviated from the federal norm was not a permissible end of congressional legislation under the commerce clause.

The higher level of scrutiny applied in National League of Cities also meant that the Court would no longer defer to Congress' judgment as to the best means of achieving its national regulatory goals. As explained previously, judicial inquiry into "less restrictive alternatives" is a feature of a high level of judicial scrutiny but not of a low level; ${ }^{137}$ in the latter case, but not the former,

134. National League of Cities, 426 U.S. at 848.

135. Id. at 847 .

136. Id. at 848.

137. See supra note 42; cf. Shelton v. Tucker, 364 U.S. 479, 488 (1960)("The breadth of legislative abridgment must be viewed in the light of less drastic means for achieving the same basic purpose."); United States Trust Co. v. New Jersey, 431 U.S. 1, 31 (1977)(“[a] State is not free to impose a drastic impairment [of its contracts] when an evident and more moderate course would serve its purposes equally well"). 
Congress need not legislate with precision, ${ }^{138}$ and may proceed "one step at a time."138 The National League of Cities majority would have required Congress to consider whether its regulation unduly burdened state sovereignty:

It is not enough that the "end be legitimate"; the means to that end chosen by Congress must not contravene the spirit of the Constitution . . . . [T] he means by which national power is exercised must take into account concerns for state autonomy .... [For example], Congress in the exercise of its taxing and spending powers can protect federal savings and loan associations, but if it chooses to do so by the means of converting quasi-public state savings and loan associations into federal associations, the Court has held that it contravenes the reserved powers of the States because the conversion is not a reasonably necessary exercise of power to reach the desired end. ${ }^{140}$

Moreover, like the jurisprudence of the Lochner Court before it, the jurisprudence of National League of Cities implicitly emphasized the superior authority and competence of the federal judiciary in contrast to that of the national legislature. It was for this reason that the Court did not have to defer to considered congressional judgments as to the proper allocation of regulatory power between the states and the federal government. This strain of thought is most explicit in Justice Powell's dissent in Garcia:

More troubling than the logical infirmities in the Court's reasoning is the

The quote from United States Trust Co. indicates another area in which the Burger Court has adopted a higher standard of scrutiny in economic regulation cases; the contracts clause. See also Allied Structural Steel Co. v. Spannaus, 438 U.S. 234 (1978)(striking down Minnesota Private Pension Benefits Act, which "superimpos[ed] pension obligations upon the company conspicuously beyond those that it had voluntarily agreed to undertake"). Id. at 240 . Interestingly enough, the cases which the Court relied on to invalidate the Minnesota statute in Spannaus were all decided in the Lochner era, and reflect that era's hostility to economic regulation of contractual relations. E.g., Triegle v. Acme Homestead Ass'n, 297 U.S. 189 (1936); W.B. Worthen Co. v. Kavanaugh, 295 U.S. 56 (1935); W.B. Worthen Co. v. Thomas, 292 U.S. 426 (1934); Home Bldg. \& Loan Ass'n v. Blaisdell, 290 U.S. 398 (1934). Except for Blaisdell (which presages the modern doctrinal treatment), each of these cases struck down a state economic regulation as violative of the contract clause. By contrast, in the post-1937 era (up until Allied Structural Steel), the Court had adopted a deferential attitude in contract clause cases, consistent with its position in other cases dealing with economic regulation. See, e.g., City of El Paso v. Simmons, 379 U.S. 497 (1965).

Because United States Trust Co. and Spannaus represent a break with post-1937 treatment of the contract clause, and because they stand for closer judicial scrutiny of economic regulations, it is likely that they reflect the same ideology which spawned National League of Cities. This conclusion is strengthened by the fact that the revolution in contract clause jurisprudence has proved to be just as short-lived as the revolution in tenth amendment jurisprudence. Just as the Court has moved away from the implications of National League of Cities in succeeding cases, the Court has subsequently retreated from the implications of United States Trust Co. and Spannaus. See Exxon Corp., v. Eagerton, 462 U.S. 176 (1983); Energy Reserves Group, Inc. v. Kansas Power \& Light Co., 459 U.S. 400 (1983).

138. See, e.g., New Orleans v. Dukes, 427 U.S. 297, 303 (1976).

139. See, e.g., Railway Express, 336 U.S. at 110.

140. Garcia, 105 S. Ct. at 1036 (O'Connor, J., dissenting) (citing Hopkins Federal Savings \& Loan Ass'n v. Cleary, 296 U.S. 315 (1935)). Note the vintage of the Hopkins case which Justice O'Connor relies on; it was decided during the Lochner era, one year before Carter $v$. Carter Coal. 
result of its holding, i.e., that federal political officials, invoking the Commerce Clause, are the sole judges of the limits of their own power. This result is inconsistent with the fundamental principles of our constitutional system. See, e.g., The Federalist No. 78 (Hamilton). At least since Marbury v. Madison it has been the settled province of the federal judiciary "to say what the law is" with respect to the constitutionality of acts of Congress. 1 Cranch 137, 177 (1803). In rejecting the role of the judiciary in protecting the States from federal overreaching, the Court's opinion offers no explanation for ignoring the teaching of the most famous case in our history. ${ }^{141}$

Finally, underlying the higher level of scrutiny in National League of Cities is a belief that the national political processes do not adequately protect state interests, and that it is therefore the duty of the federal judiciary to scrutinize congressional legislation to ensure that state interests are protected. This is a departure from the ideology of Carolene Products and Darby, which assumed that where only economic rights were at stake, any undesirable regulatory legislation would be eliminated through democratic processes which were assumed to be functioning properly. Just as the Lochner Court feared the redistributive motivations of state and federal legislators, the National League of Cities majority feared that Congress would not have sufficient incentives to protect state interests and state sovereignty. Once again, the ideological assumption that there is a failure of democratic process is made most explicitly in Justice Powell's dissent in Garcia:

[W]e have witnessed in recent years the rise of numerous special interest groups that engage in sophisticated lobbying, and make substantial campaign contributions to some members of Congress. These groups are thought to have significant influence in the shaping and enactment of certain types of legislation. Contrary to the Court's view, a "political process" that functions in this way is unlikely to safeguard the sovereign rights of States and localities. ${ }^{142}$

Federal legislation is drafted primarily by the staffs of the congressional committees. In view of the hundreds of bills introduced at each session of Congress and the complexity of many of them, it is virtually impossible for even the most conscientious legislators to be truly familiar with many of the statutes enacted. Federal departments and agencies customarily are authorized to write regulations. Often these are more important than the text of the statutes. As is true of the original legislation, these are drafted largely by staff personnel. The administration and enforcement of federal laws and regulations necessarily are largely in the hands of staff and civil service employees. These employees may have little or no knowledge of the States and localities that will be affected by the statutes and regulations for which they are responsible. In any case, they hardly are as accessible and responsive as those who occupy analogous positions in State and local governments. ${ }^{143}$

141. Id. at 1026-27.

142. Id. at 1031 n.18.

143. Id. at 1031 . 


\section{GARCIA AND THE REASSERTION OF THE DOMINANT IDEOLOGY IN JUDICIAL REVIEW OF ECONOMIC REGULATION}

Once the parallels between the jurisprudence of Lochner and National League of Cities are made clear, the corresponding connections between the post-1937 cases and Garcia are obvious. Garcia bears the same relationship to National League of Cities that United States v. Darby bore to Hammer $v$. Dagenhart, or that United States $v$. Carolene Products bore to Adkins v. Children's Hospital. Moreover, for each feature of Lochner jurisprudence we saw recapitulated in National League of Cities, there is a corresponding feature of the dominant post-1937 jurisprudence which is recapitulated in Garcia.

\section{A. Market Regulation and a Preference for Federal Regulatory Power over State Power}

Garcia made explicit an assertion of the primacy of federal power over state power:

We doubt that courts ultimately can identify principled constitutional limitations on the scope of Congress' Commerce Clause powers over the States merely by relying on a priori definitions of state sovereignty . . . [T] $]$ he sovereignty of the States is limited by the Constitution itself . . . .

The states unquestionably do "retai[n] a significant measure of sovereign authority . . . ." They do so, however, only to the extent that the Constitution has not divested them of their original powers and transferred those powers to the Federal Government . ...

The power of the Federal Government [like that of the States] is a "power to be respected" . . . and the fact that the States remain sovereign as to all powers not vested in Congress or denied them by the Constitution offers no guidance about where the frontier between state and federal power lies. In short, we have no license to employ freestanding conceptions of state sovereignty when measuring congressional authority under the Commerce Clause. ${ }^{144}$

Garcia does not make explicit the connection between the primacy of federal power and a communalist orientation in economic regulation cases; that is, the preference for uniform market regulation of freedom of contract. That connection is, of course, implicit in both Garcia and in EEOC v. Wyoming. These cases uphold the federal interest in ensuring that minimum wages are paid to all workers and the interest in protecting all workers from the effects of undesirable discrimination. Both of the regulations involved in these cases abridged the "State freedom of contract" which underlay National League of Cities.

A more explicit statement of the rejection of values of economic individualism in favor of uniform market regulation appears in Justice Stevens' concurrence in EEOC $v$. Wyoming, in which he urged the Court to overrule National

144. Id. at 1016-17 (quoting EEOC v. Wyoming, 460 U.S. 226, 269 (1983)). 
League of Cities. ${ }^{145}$ Interestingly enough, Stevens is an economic conservative who has stated his personal opposition to various forms of market regulation in the private sector. ${ }^{146}$ Yet, ironically, it is Stevens who emphasizes the interdependence of individual economic actors in the national economy - a clearly communalist orientation underlying post-1937 ideology. And it is Stevens who makes the most cogent arguments for recognizing the federal government's power to limit state freedom of contract as well as private freedom of contract in order to achieve a uniform federal economic policy:

There have been occasions when the Court has given a miserly construction to the Commerce Clause. But as the needs of a dynamic and constantly expanding national economy have changed, this Court has construed the Commerce Clause . . . to confer a power on the National Government adequate to discharge its central mission . . . . The development of judicial doctrine has accommodated the transition from a purely local, to a regional, and ultimately to a national economy. ${ }^{147}$

Because of the interdependence of the segments of the economy and the importance and magnitude of government employment, a comprehensive congressional policy to regulate the labor market may require coverage of both public and private sectors to be effective. ${ }^{148}$

\section{B. The Rejection of the New Conceptualism and the Public/ Private Distinction}

I have already noted that the public/private distinction was both the essential foundation of National League of Cities and the source of its eventual demise. I have also noted that National League of Cities and Hodel could not have represented a full-blown exercise in the old-fashioned conceptualism of the Lochner era. The sort of conceptualist reasoning which had thrived in the Lochner era was unsuited to the intellectual climate of post-1937 jurisprudence, at least in economic regulation cases. The considerable influence of the Legal Realist attacks on Lochner era conceptualism, ${ }^{140}$ the abandonment of liberty of contract as a preferred liberty under the due process clause and the combined weight of post-1937 precedents made a return to conceptualism in economic regulation cases difficult. ${ }^{150}$ For this reason, the only overtly concep-

145. EEOC v. Wyoming, 460 U.S at 250.

146. See id.; National League of Cities, 426 U.S. at 881 (Stevens, J., dissenting).

147. 460 U.S. at $246-47$ (Stevens, J., concurring).

148. Id. at 248.

149. E.g., Cohen, Transcendental Nonsense and the Functional Approach, 35 CoLum. L. REv. 809 (1935).

150. This is not to say that conceptualism does not survive in modern cases. Conceptualism flourishes in any area of law where rights are seen as fundamental, absolute and not subject to balancing against rights on the other side. Thus, one might classify Justice Black's and Justice Douglas' writing in First Amendment cases as conceptualist. Their assertions that people should be free to make even the most trivial, obscene or harmful expressions can be compared to the Lochner Court's championing of the freedom of contract of the worker and the employer, no matter what degree of harm accrued to the public in general or the worker in particular. 
tualist move in National League of Cities was the assertion of the public/private distinction. However, even that limited move was gradually recognized to be untenable.

In fact, the beginning of the decline of the conceptualist approach in $\mathrm{Na}$ tional League of Cities can be traced to Justice Blackmun's limiting concurrence in that case itself. Blackmun's vote was necessary to form a five-person majority in National League of Cities, and he joined the Court's opinion because he read it as requiring a case-by-case balancing of competing federal and state interests. ${ }^{101}$

A balancing approach is inimical to a conceptualist jurisprudence, which does not see rights in conflict which need to be balanced but rather sees carefully demarcated and mutually exclusive spheres of individual rights (or in this case, of state and federal sovereignty). Indeed, it was only as the Lochner era drew to a close that the Supreme Court Justices began to recognize that the differences between public and private interests, or direct and indirect effects, were matters of degree and not of kind. It was this recognition, and the recognition of the need to balance competing interests, which led to the intellectual dissolution of the Lochner ideology.

Thus, Justice Blackmun's limiting concurrence grafted onto the Court's quasi-conceptualist test of "integral state functions" a modern balancing approach: a pragmatic and non-conceptualist test representing the jurisprudence of the modern era. This cheek-by-jowl juxtaposition continued in Hodel: The Court announced a set of three factors which would determine if there was an impairment of an integral state function, and then stated that at the conclusion of this three factor test it would apply a further balancing test. ${ }^{152}$ Clearly there was an intellectual disharmony between the first part of the Hodel test and the second part necessitated by Justice Blackmun's concurrence. If the sovereign province of the "States as States" had indeed been invaded by federal regulation, there was no legitimate federal interest or federal regulatory power; one really should not have gone on to consider the relative weight of federal and state concerns. Indeed, Justice Rehnquist, who had to go along with Blackmun's concurrence to get his original majority in National League of Cities, appeared to be unhappy with a balancing test for this very reason, as

These same Justices, of course, took a very non-conceptualist attitude in cases involving economic regulation, as they supported the overturning of Lochner era precedents. However, this seeming inconsistency is not at all unusual. In the post-1937 era first amendment rights are specially protected, while economic rights are not. Conceptualist forms of reasoning go hand in hand with a high degree of judicial scrutiny in cases involving protected liberties. Because Black and Douglas supported a communalist philosophy in economic regulation cases and an individualist philosophy in First Amendment cases, they were conceptualist in their reasoning as to the latter and anti-conceptualist as to the former. Similarly, more conservative justices like Justice Frankfurter, Justice Harlan, or Justice Powell are likely to take a non-conceptualist approach to first amendment cases and emphasize the need for balancing the interests of the speaker against those of the government.

151. National League of Cities, 426 U.S. at 856 (Blackmun, J., concurring).

152. Hodel, 452 U.S. at 288 n.29. 
he pointed out in Garcia:

Justice Powell's reference [in his dissent in Garcia] to the "balancing test" approved in National League of Cities is not identical with the language in that case, which recognized that Congress could not act under its commerce power to infringe on certain fundamental aspects of state sovereignty that are essential to "the States' separate and independent existence."16s

Garcia, of course, rejects a theory that the states have absolute rights or clearly demarcated spheres of state sovereignty, because it holds that Congress is best suited to determine the boundaries of federal and state authority through legislation passed by representatives of the people and the States. However, there is an even more overtly anti-conceptualist move in Garcia. The Court's basic justification for overruling National League of Cities was the incoherence and arbitrariness of the "integral state functions" test. That test, in turn, was the modern version of the public/private distinction which had been the linchpin of the decision in National League of Cities. Interestingly, the Court even compared the test of National League of Cities to the governmental/proprietary distinction developed in the Lochner period:

The district court [in the case below] voiced a common concern: "Despite the abundance of adjectives, identifying which particular state functions are immune remains difficult." 557 F. Supp. at 447 . . . [C]ourts have held that regulating ambulance services, licensing automobile drivers, operating a municipal airport, ... and operating a highway authority are functions protected under National League of Cities. At the same time, courts have held that issuance of industrial development bonds, regulation of intrastate natural gas sales, regulation of traffic on public roads, regulation of air transportation, operation of a telephone system, leasing and sale of natural gas, operation of a mental health facility, and provision of in-house domestic services for the aged and handicapped are not entitled to immunity. We find it difficult, if not impossible, to identify an organizing principle that places each of the cases in the first group on one side of a line and each of the cases in the second group on the other side ....154

$\cdots$

A further cautionary note is sounded . . . by the Court's experience in the related field of state immunity from federal taxation . . . . While the Court applied the [governmental/proprietary distinction] for . . . 40 years, at no time during that period did the Court develop a consistent formulation of the kinds of governmental functions that were entitled to immunity.

The distinction the Court discarded as unworkable in the field of tax immunity has proved no more fruitful in the field of regulatory immunity under the Commerce Clause. ${ }^{155}$

Thus we can see that the abandonment of the distinction between public

153. Garcia, 105 S. Ct. at 1033 (Rehnquist, J., dissenting).

154. Id. at 1011-12 (citations omitted).

155. Id. at 1012-14. 
and private purposes in the post- 1937 era is recapitulated in Garcia's rejection of the public/private distinction underlying National League of Cities.

\section{Legislative Competence and Authority and a Low Level of Judicial Scrutiny}

Garcia reaffirms the committment made in Darby and Carolene Products to judicial deference in economic regulation cases. Once again the Court emphasized that the federal judiciary lacked the competence and the authority to determine the proper allocation of regulatory authority between the states and the federal government:

Any rule of state immunity that looks to the "traditional," "integral," or "necessary" nature of governmental functions inevitably invites an unelected federal judiciary to make decisions about which state policies it favors and which ones it dislikes....

…

We . . . reject, as unsound in principle and unworkable in practice, a rule of state immunity from federal regulation that turns on a judicial appraisal of whether a particular governmental function is "integral" or "traditional." Any such rule leads to inconsistent results at the same time that it disserves principles of democratic self-governance, and it breeds inconsistency precisely because it is divorced from those principles. ${ }^{156}$

Just as in the Court had done in Darby and Carolene Products, the Garcia Court emphasized the authority and competence of Congress to make the very judgments that the federal courts could not make. At the same time, the Garcia Court postulated the same degree of trust in democratic political processes that underlay the decisions in Darby and Carolene Products. Legislation which undesirably infringed upon state sovereignty could surely be overturned by resort to legislative remedies, for there was no reason to think the States were not adequately represented in Congress or that the democratic processes were not working correctly:

[T] he principal means chosen by the Framers to ensure the role of the States in the federal system lies in the structure of the Federal Government itself .... The States were vested with indirect influence over the House of Representatives and the Presidency .... They were given more direct influence over the Senate, where each state received equal representation .... [The Constitution prohibits] any constitutional amendment divesting a State of equal representation [in the Senate] without the State's consent. ${ }^{157}$

The effectiveness of the federal political process in preserving the States' interests is apparent even today in the course of federal legislation .... [F]ederal grants now account for about one-fifth of state and local government expenditures .... . [The States] have been able to exempt themselves from a wide variety of obligations imposed by Congress under the Commerce

156. Id. at 1015-16.

157. Id. at 1018. 
Clause. ${ }^{188}[\mathrm{~T}]$ he principal and basic limit on the federal commerce power is that inherent in all congressional action - the built-in restraints that our system provides through state participation in federal governmental action. The political process ensures that laws that unduly burden the States will not be promulgated. In the factual setting of these cases the internal safeguards of the political process have performed as intended.

...

In sum, in National League of Cities the Court tried to repair what did not need repair.'159

\section{IDEOLOGY AND IRONY IN NATIONAL LEAGUE OF CITIES AND GARCIA}

There is a delicious irony to the Garcia dissenters' solicitous concern with failures of process and the need for judicial protection of the interests of the states, and the Garcia majority's assurances that no failure of process exists. In case after case involving the protection of rights or interest groups dear to the more liberal members of the Court, the Garcia dissenters have counseled against judicial assertions of power favored by the liberals on the grounds that the political process is the best remedy to undesirable governmental action. ${ }^{180}$ However, in Garcia, the more liberal members of the Court assert that the political process will adequately represent the interests of the states, a claim bitterly contested by the conservatives.

That is not the only irony of the National League of Cities and its progeny leading up to Garcia. Three of the Garcia dissenters (Rehnquist, Burger, Powell) have been the Justices most often associated with the philosophy of judicial restraint, while Justices Brennan and Marshall, members of the Garcia majority, have been characterized as judicial activists. However, in Garcia, it is the dissenters who emphasize the importance of the federal judiciary's role in overseeing congressional action which affects the states, and it is the majority which preaches the need for judicial restraint and deference to considered legislative judgments.

National League of Cities and its progeny teach a very important lesson about the nature of institutional arguments. It is apparent that it is the substantive right being asserted which determines whether Justices think the political process is working satisfactorily or needs judicial supervision.

Put another way, the lesson of National League of Cities and Garcia is that there are no true judicial activists or judicial passivists in this world. There are only judges with particular conceptions of substantive rights, and judges with particular ideological biases. The most virulent advocate of judicial restraint can become a flaming judicial activist who will strike down the legislative judgments of a popularly elected majority to satisfy his ideological crav-

158. Id. at 1019 .

159. Id. at 1020-21.

160. See, e.g., United States v. Richardson, 418 U.S. 166 (1974); San Antonio Indep. School Dist. v. Rodriguez, 411 U.S. 1 (1973). 
ings. The most radical judicial activist will preach restraint and respect for democratic institutions if in doing so he can uphold legislation which comports with his ideological agenda. The more piously judges make institutional arguments about the duty of the federal judiciary, the more sure we can be that the reasons which they use to convince are not the reasons which convinced them.

\section{THE UNANSWERED QUESTIONS OF GARCIA}

I have claimed that the post-1937 orientation in economic regulation cases is an ideology, and that Garcia represents a continuation of that ideology. As an ideology, the post-1937 jurisprudence acts as both a justification and apology for the present status of economic regulatory power (both public and private) in this country. Moreover, as an ideology, it paints a partially false picture of political reality. I would like to conclude this study by pointing out the nature of this falsification and by suggesting the work that the Court has before it, if it wishes to transcend its ideological constraints.

Garcia rests upon an assumption that political processes are adequate to protect the interests of the states. For this reason, it was unnecessary, at least in the context of the case before it, for the Court to "identify or define what affirmative limits the constitutional structure might impose on federal action affecting the States under the Commerce Clause."161

However, one does not have to agree with the ideological presuppositions of Justices Rehnquist and Powell to acknowledge that democratic processes sometimes do fail us, and that it is certainly possible that they might fail in the area of protecting state and local interests. The simple statement of faith that the processes will never fail to protect state and local interests is as ideological as anything in National League of Cities itself.

The post-1937 ideology does postulate that the political process sometimes fails to protect individual liberties, and that the reasons may be systemic. It also recognizes that majoritarian bodies may pass laws which burden individual rights or suspect classes and are unlikely to be corrected through lobbying efforts. This insight underlies the famous footnote four of Carolene Products. ${ }^{182}$

If it is sometimes necessary for the Court to correct majoritarian processes in order to protect individuals, why should we think it is never necessary to correct those same processes to protect state and local interests? And if we know that somewhere along the line, the process will fail to protect the interests of state and local governments, does that not justify judicial supervision and a high level of scrutiny along the lines of Carolene Products ${ }^{\text {?6s }}$

161. Garcia, $105 \mathrm{~S}$. Ct. at 1020.

162. 304 U.S. at 152 n.4. For a more recent version of this theory, see J. Ely, DemocracY AND Distrust (1980). As explained earlier, a given ideological view is more likely to recognize the existence of failures of process to protect what that ideology views as preferred rights or interests than failures of process to protect nonpreferred rights or interests.

163. Of course, the above argument assumes that states and local governments have judicially 
What Garcia leaves us with, as Darby before it, is a version of Carolene Products without a corresponding justification for judicial review where it is really needed: that is, without an equivalent to footnote four. Justice Powell's dissent in Garcia may be seen as merely an eloquent statement of the problem left to future decisions.

The Court is now left with the task of developing a theory which explains when and how courts will protect state and local interests where the national political process fails to do so. The eventual form this doctrine takes may look very different from the type of doctrine the Court has developed in the due process and equal protection areas with respect to individual rights. After all, there is no reason to expect that the states stand in exactly the same footing as individuals. Nor need such a doctrine require the Court to sacrifice specially protected individual rights at the altar of state sovereignty. On the contrary, the institutional rights and responsibilities of states versus the federal government cannot be properly demarcated without reference to the protection of individual rights.

The unanswered questions of Garcia are of considerable importance. It remains to be seen whether the Court will take a fresh approach to them or continue to do what it has done before: bounce back and forth from one set of ideological biases to another.

cognizable "rights" under our constitutional scheme, or, what is the same thing, that they have interests that the federal courts must take into account and protect from encroachments by the federal government or failures of the national political process. Although my argument does make this assumption, it is justified on the basis of the text and history of the Constitution itself.

The separate and continued existence of the states as partial sovereigns seems to me a fundamental postulate in our constitutional scheme. If so, there must be some "rights" or interests that the states retain that are worthy of judicial protection, unless one assumes that all issues of federalism are "political questions" which are left to decision by the political branches. However, I would have a great deal of difficulty reconciling that position with the Court's practice of holding state statutes preempted by federal legislation, or by the commerce clause itself. Clearly, if the courts are permitted to vindicate federal rights at the expense of state interests they should be permitted to decide whether state's rights should be vindicated at the expense of federal interests. 